\title{
Miocene Rocks Around the Marádah Oasis, Central Sirt Basin, Libya: Facies Development and Implication on Stratigraphy
}

\author{
Esam O. Abdulsamad ${ }^{1}$, Saleh A. Emhanna ${ }^{2}$, Ramzi S. Fergani ${ }^{3}$, Hamad N. Hamad ${ }^{3}$, Moataz A. Makhlouf ${ }^{3}$, \\ Hamad A. Asbeekhah ${ }^{3}$, Ali K. Khalifa ${ }^{3}$ \& Mohammed H. Al Riaydh ${ }^{1}$ \\ ${ }^{1}$ Department of Earth Sciences, University of Benghazi, University Road 13, P.O.B. 9480, Benghazi, Libya \\ ${ }^{2}$ Department of Petroleum Engineering, University of Ajdabiya, City Road 1, P.O.B. 291, Ajdabiya, Libya \\ ${ }^{3}$ Department of Geological Engineering, Bright Star University, City Road 11, P.O.B. 21864, Al Brega, Libya \\ Correspondence: Esam O. Abdulsamad, Department of Earth Sciences, University of Benghazi, University Road 13, \\ P.O.B. 9480 Benghazi, Libya. E-mail: esam000@yahoo.com
}

Received: November 15, 2020

Accepted: December 31, 2020

Online Published: January 13, 2021

doi:10.5539/esr.v10n1p8

URL: https://doi.org/10.5539/esr.v10n1p8

\begin{abstract}
The Miocene rocks of the Marádah Formation have been stratigraphically investigated from four stratigraphical sections around the Marádah Oasis in the Central Sirt Basin of Libya. The field investigations led to the identification of two members, the lower Qarat Jahannam Member and the upper Ar Ráhlah Member. Fourteen sedimentary facies at the outcrop-scale representing a gradual development of sedimentation from a continental clastic witness in the southwestern outcrops to transitional estuarine, lagoonal, and beaches to the proximal offshore in the northern outcrops, were recognized. The results indicates that the accumulation of the Marádah Formation is transgressive in nature and corresponding to two phases of deposition which have been mentioned in the earlier studies.

The first phase is continental-dominated facies in which cross-bedded sandstones and calcareous sands comprise most of the depositional sequence of the lower Qarat Jahannam Member at the southwestern outcrops. This phase, however, is characterized by extremely bioturbated laminated-shale conquered by Skolithos ichnofacies in the lower part of the upper Ar Ráhlah Member at the northern outcrops. This phase is providing further evidence that the contact between the two members is diachronous everywhere in the study area. The clastic-phase has thought to be deposited in the Lower Miocene (Aquitanian-Burdigalian) since the lower Qarat Jahannam Member rests on an erosional surface of submarine origin in the southwestern outcrops above a $0.5 \mathrm{~m}$. thick of a nummulitic unit of the Oligocene Bu Hashish Formation.

The second phase is marine-dominated facies in which a bioclastic limestone unit rich in thick and disarticulated oysters, including Crassostrea gryphoides (Schlottheim), characterizes the sediments of the Ar Ráhlah Member at the southwestern outcrops. This phase also includes the upper part of the latter member at the northern outcrops in which a detrital limestone unit rich in turritelline gastropods is overlying by thick-bedded calcarenites rich in disarticulated oysters, gastropods, irregular echinoids (notably, Clypeaster and Echinolampas), bryozoans, and celestite corals. The upper part of the Ar Ráhlah Member at the northern outcrops, nevertheless, is terminated by a quite hard dolomitic limestone and by a pretty soft dolomitic marly limestone. Both lithologies, however, are combined with medium-sized oysters, including Ostrea digitalina Fuchs, and pectinid bivalves. The second phase, however, is interpreted to be deposited in the Middle Miocene (Langhian and Serravallian) based on the total-stratigraphic range of the larger benthic foraminifera Borelis melo melo (Fichtel \& Moll), which recovered from the studied washed residues, and the associated microfacies.
\end{abstract}

Keywords: Libya, Sirt Basin, Miocene, Marádah Formation, Sedimentary Facies

\section{Introduction}

The Oasis of Marádah lies about $120 \mathrm{~km}$ inland from the Mediterranean coast in the Sahara Desert of Libya (Figure 1). On the northern side of the Oasis, the majority of rocks are cropping out in more or less east-west elongate scarps with an elevation of more than 150 meters reported in the northeast. On the southern side of the Oasis, however, several residual table hills rise from the plains ranging in height from a few meters to over 300 meters reported in the southwest. Geologically, the entire region is belonging to the central part of the Sirt Basin.

The whole of the sequence, nevertheless, is built-up of horizontal to subhorizontal strata with a general dip of few degrees 
toward the NE direction. The sequence is dissected by some isolated hills, and several wadis and it consist of clastic and carbonate sedimentary rock units that were laid-dawn in the Lower-Middle Miocene (Maštera, 1985). Lithological variation, however, is abrupt both vertically and laterally, making the correlation of beds somehow difficult. In general, however, marine-dominated facies (principally, calcarenite limestones) become more abundant in the northern scarps whereas continental-dominated facies (notably, calcareous sandstones and unconsolidated sands) increase in importance in the southern escarps.

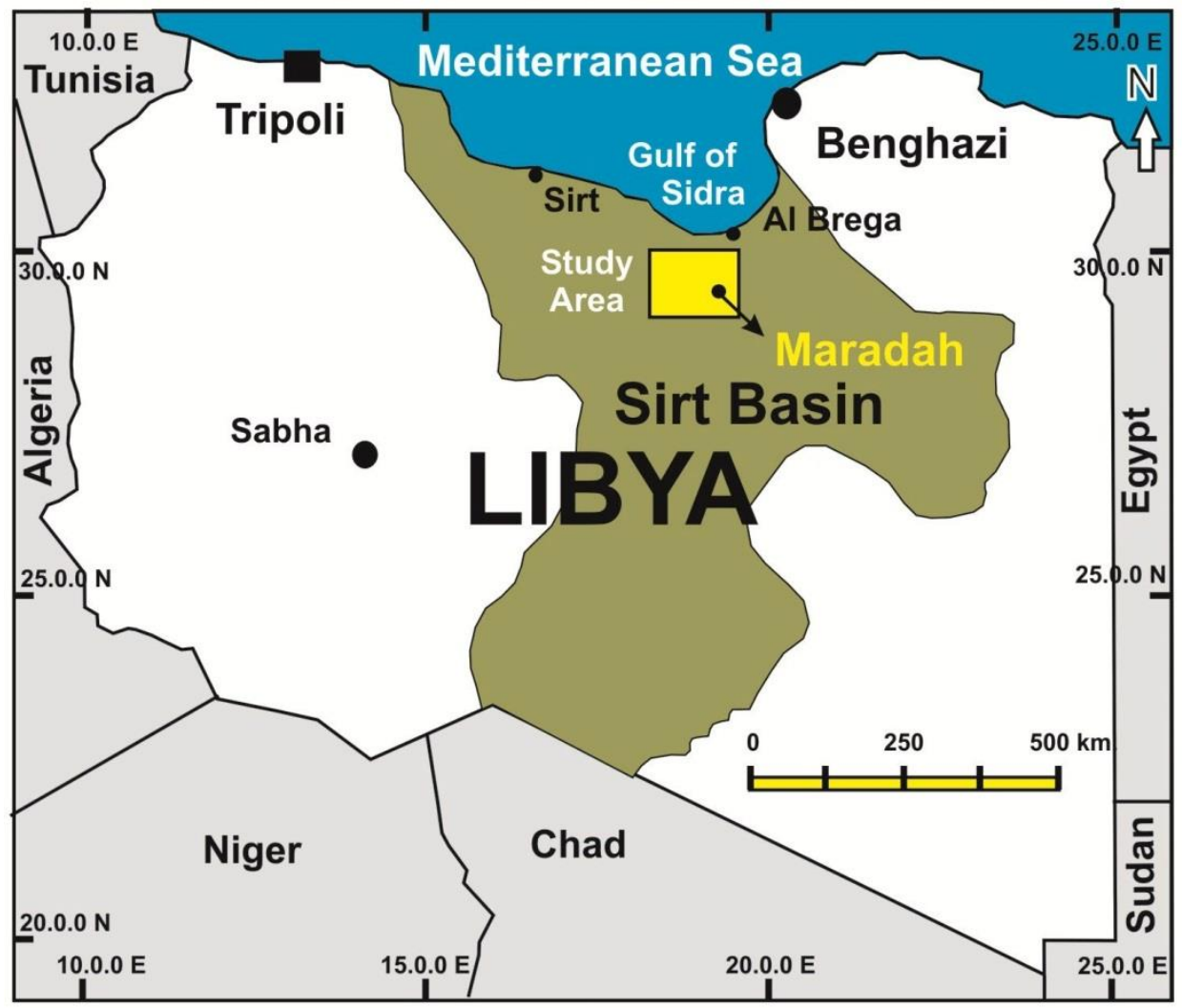

Figure 1. Index map of Libya showing the location of the studied area. The boundaries of the Sirt Basin are represented hereafter by Abdunaser and McCaffrey (2015)

In the current study, four stratigraphic sections of the Marádah Formation were measured and systematically sampled (Figure 2). The first and second sections (S1 and S2) are up to $100 \mathrm{~m}$ in thickness and were measured in the south-western side of the Marádah Oasis (Figure 3). The majority of the sequence in this locality is considered here to represent the Qarat Jahannam Member (Maštera, 1985) which corresponds to the continental-dominated facies. The third and fourth sections (S3 and S4), however, are up to $80 \mathrm{~m}$ in thickness and were measured at the northern part of the Marádah Oasis (Figure 4). They are considered here to represent the Ar Ráhlah Member (Maštera, 1985) in which the lower part of the member corresponds to the continental-dominated facies whereas the upper part corresponds to the marine-dominated facies. To understand the lateral continuity of the studied deposited, all sections, though, have been compiled by spot samples, from different isolated hills in the northern and south-western parts of the Marádah Oasis. All measured sections, nevertheless, are located broadly between latitudes $18^{\circ} .00^{\prime}$ and $19^{\circ} .30^{\prime} \mathrm{E}$ and longitudes $29^{\circ} .00^{\prime}$ and $30^{\circ} .00^{\prime} \mathrm{N}$ (see Figure 2). 


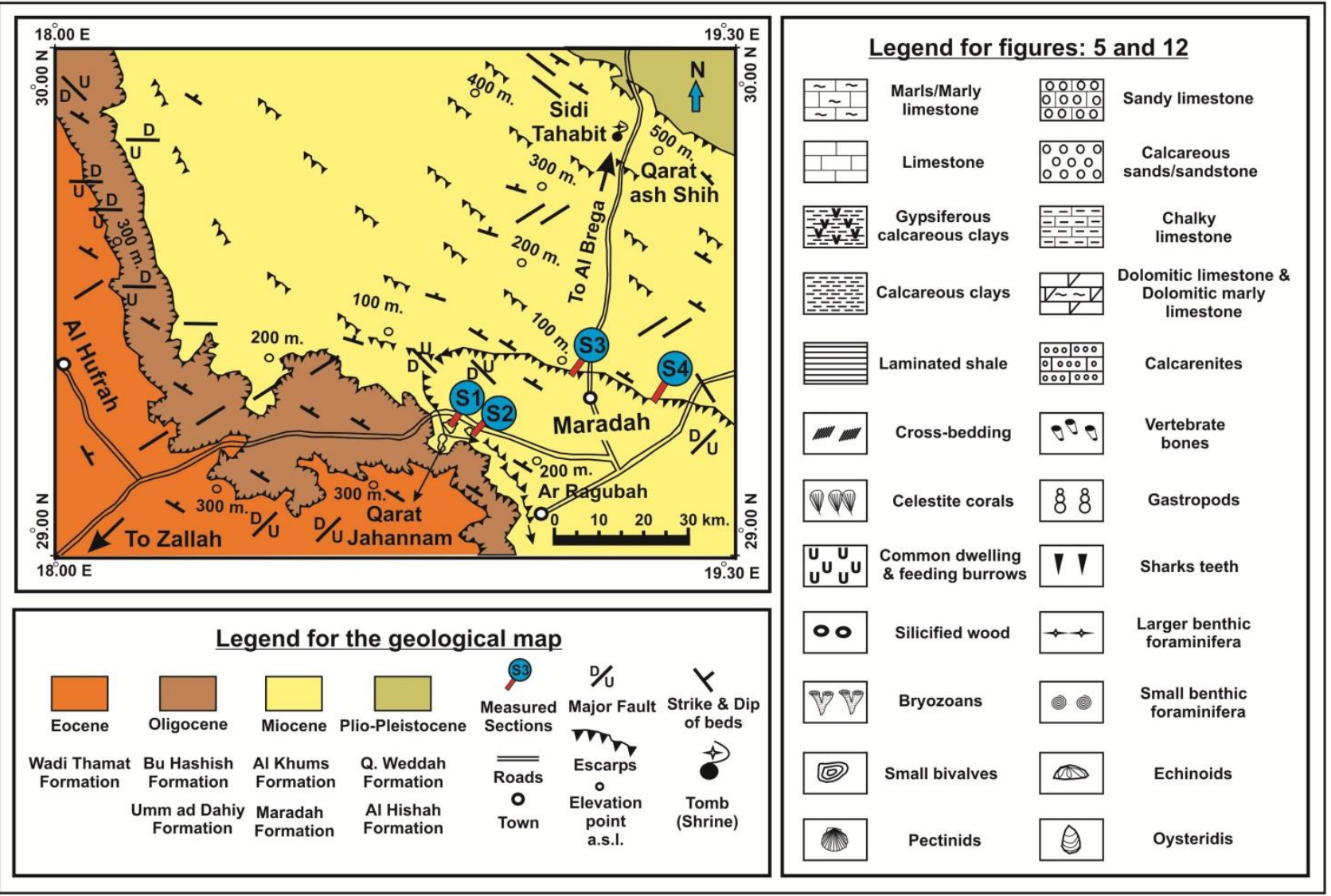

Figure 2. Geological map of the Marádah area showing the locations of the studied sections (S1-S4) modified after Maštera (1985)

The current study is part of a larger project to revise the surface outcrops of the Sirt Basin in which has been received little attention in the last two decades compared to the subsurface. The project starts with two publications on the stratigraphy and sedimentology of the western part of the Sirt Basin. The first study is discussed the Upper Cretaceous to Upper Paleocene succession (Abdulsamad et al., 2020a), whereas the second study is discussed the Upper Paleocene to Lower Eocene deposits (Abdulsamad et al., 2020b). The Middle Eocene to Oligocene deposits is under consideration and the results will be discussed in a separate publication. The Miocene rocks of the Marádah Formation, in the current survey, however, are described and discussed with the aim to improve the stratigraphy of the region based on information derived from the facies analysis and the associated trace and body fossil accumulation at outcrop-scale. The results, however, were also augmented by other data derived from petrographic thin-sections and washed residues of critical stratigraphic intervals wherever possible. 


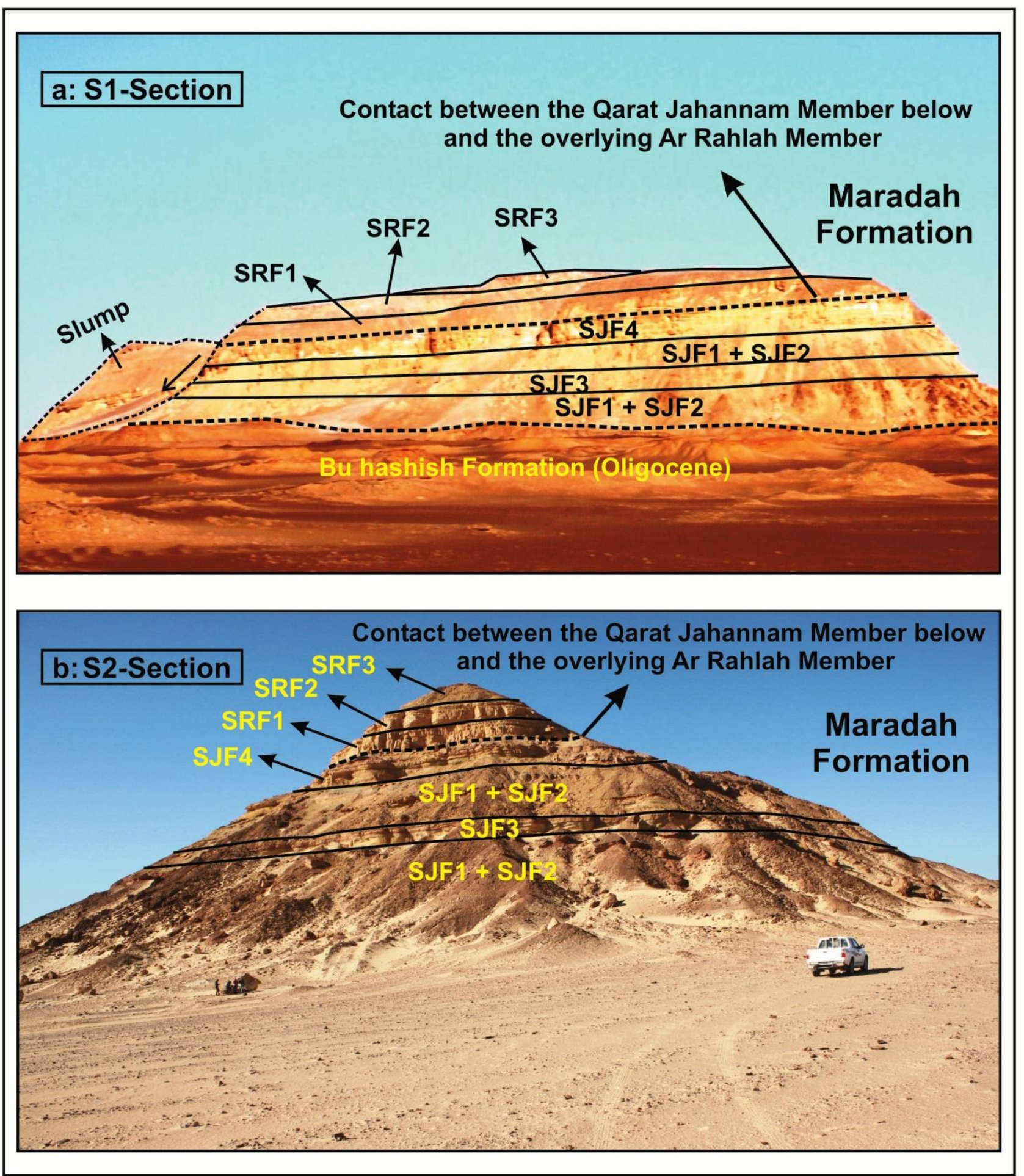

Figure 3. Views of the studied sections of the Marádah Formation showing S1-Section (a), and S2-Section (b) at the southwestern of the Marádah Oasis. SJF1-SJF4 are representing facies one to facies four which recognized in the Qarat Jahannam Member while SRF1-SRF3 are representing facies one to facies three which recognized in the Ar Ráhlah Member. The dashed line represents the contact between the Qarat Jahannam Member below and the overlying Ar Rahlah Member 

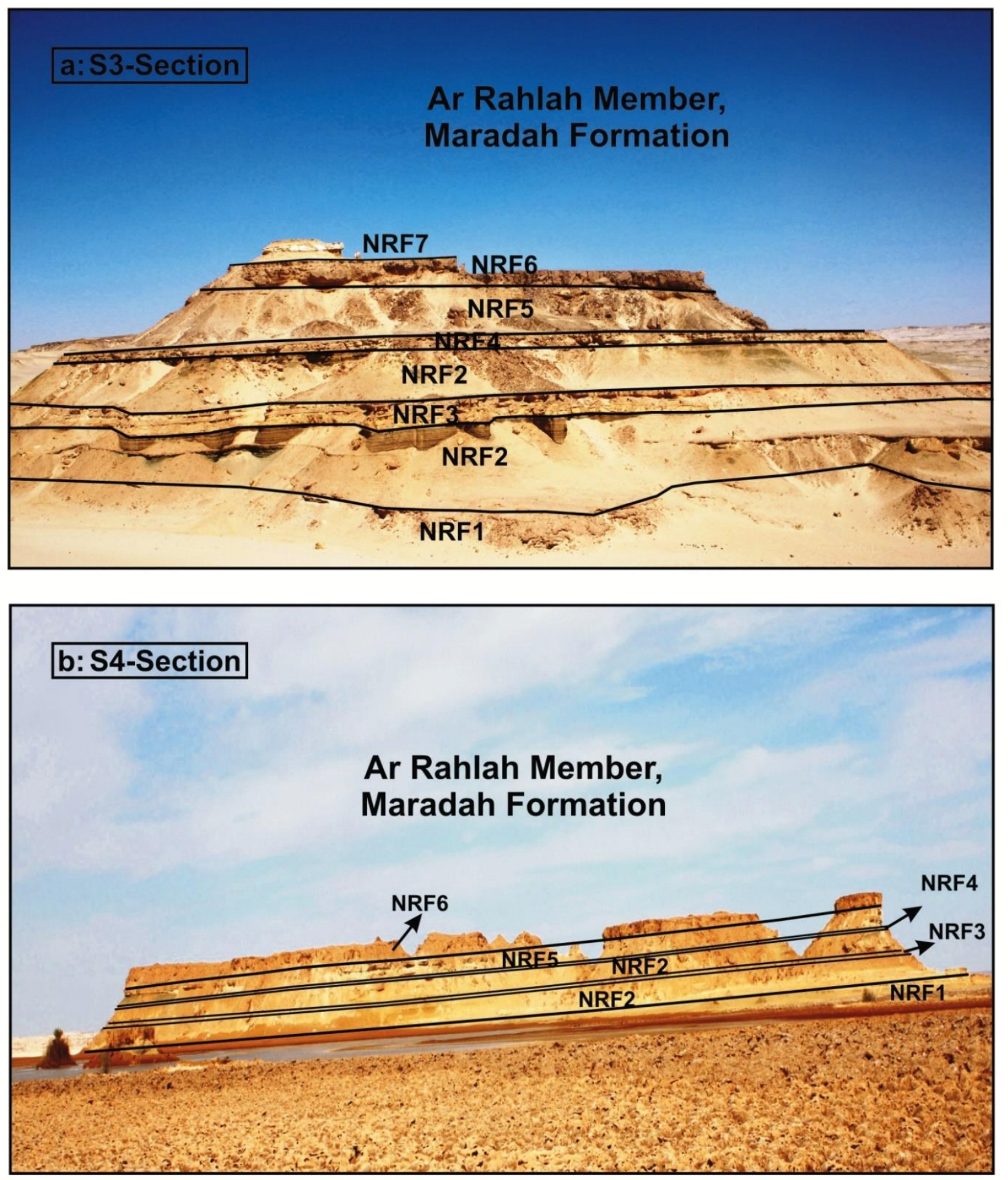

Figure 4. Views of the studied sections of the Marádah Formation showing S3-Section (a), and S4-Section (b) at the northern of the Marádah Oasis. NRF1-NRF7 is representing facies one to facies seven in the Ar Ráhlah Member

\section{Materials and Methods}

Outcrop samples of clastic and carbonate sedimentary rocks were collected at a maximum interval of every 2 m; near lithologic facies changes the samples were more closely spaced. Composition, sedimentary structures, bed thickness, and macrofossil content were examined using terms proposed by Tucker (2011). The majority of the hard samples collected were subsequently processed for thin-section analysis, with several lithologies being recognized. Their litho-and bioclastic components are expressed using terms recommended by Flügel (2010). Several samples of soft lithologies, however, were crushed and disaggregated in a hydrogen peroxide solution and washed through a $63-\mu \mathrm{m}$ sieve. Although, 
almost all samples were barren of microfossils, few samples from critical levels, however, are containing foraminifera, ostracods, and shell-fragments of mollusks, echinoids, and bryozoans. Unfortunately, the recovered specimens (mostly foraminifera) were poorly preserved and none of them were good enough for photomicrographs. We were able, nevertheless, to identify few specimens including some specimens of miliolids and alveolinids. Selected carbonate samples from the studied rock unit were also inspected for the study of calcareous nannofossils for age determination; however, the calcareous nannofossil samples did not yield any recovery. All laboratory analyses were undertaken at the Micropaleontology Laboratory of the Earth Sciences Department of the Benghazi University.

The study material will have a final repository in the Geological Museum of the University of Benghazi (Benghazi, Libya).

\section{Background and Stratigraphy}

The first published geological account on the area was that of Desio (1935) who designated the Miocene sequences, north, and east of Marádah area, the "Marada Series". From his studies, he suggested that the rocks of the region were laid dawn along an ancient shoreline near a delta which more or less ponded a lagoon. He considered the marine-dominated facies exposed in the northern escarpment as Lower-Middle Miocene in age, whereas the continental-dominated facies exposed upon the southern escarps as Lower Miocene. Magnier and Belgiers (1959) described the Marádah Formation as Lower Miocene, distinguishing "Facies Marin Marada" and Facies Continental Zelten". Goudarzi (1970) introduced the term Marada Group and dated the unit to Middle Miocene. Both Selly $(1968,1969 ; 1971)$, and El-Hawat $(1975 ; 1980)$ have dealt with the facies development in the region and they recognized several important lithofacies. Both authors, however, assumed that their recognized facies show lateral transitions throughout the region. The work of Doust (1968), however, is quite comprehensive and included paleontological and sedimentological details from the Marádah area and southern Jabal Zelten area. In fact, these details have provided crucial evidence for the interpretation of the depositional history of the entire region. Doust (1968) recognized two phases of deposition in the region. An earlier (Lower Miocene) clastic phase found in the southern parts, indicating a tropical savannah climate, and a later phase (Middle Miocene) of carbonate deposition found in the northern parts, indicating shallow marine deposition. Both phases, however, are in accordance with the findings of Desio (1935), and Magnier and Belgiers (1959).

Other publications in the region were focused on the clastic deposits of the Jabel Zelten area, south of the study area, as it contains diverse fossil vertebrates. A concise overview of mammal faunas can be found in Savage and Hamilton (1973). Based on Gaziry (1987), from Jabel Zelten area, the deposits of the Marádah Formation contain mammal faunas of different ages (Middle to Upper Miocene). Small Mammal faunas from Jabal Zelten area, however, are discussed by Wessels et al. $(2003 ; 2008)$. The last two publications suggested that the age of the Marádah Formation in the southern region is Lower-Middle Miocene.

A comprehensive data of mostly Oil-prospects boreholes in the region were studied by Wright and Edmunds (1971), Barr and Weegar (1972), and Benfield and Wright (1980). Unfortunately, the results of these publications were not particularly helpful for providing further insights into the depositional history but assigned a Lower-Middle Miocene age for the deposits of Marádah Formation. More recently, El Ebaidi and Muftah (2015) present a geochemical and petrographical analysis of the Marádah Formation at Jabel Zelten. They inferred that the depositional environment is dominated by very hypersaline lagoons of arid to semi-arid conditions with a restricted shallow platform to intertidal pulses. In fact, their conclusion is based on an analysis of the clayey and dolomite horizons which represent minor deposits compared to the overwhelming calcareous sands and sandstone sediments of the rock unit at Jabel Zelten. Unlike the later study, fish excavations by Argyriou et al. (2016) from the Marádah Formation in Jabal Zaltan, however, assumed that the depositional environment of the formation was in tropical shallow estuarine to deltaic conditions.

Although the stratigraphic nomenclatures of sedimentary units of the region are contained in the work of Megerisi and Mamgain (1980), the stratigraphical subdivisions are introduced for the study region by Maštera (1985), however, has been adopted in the current work. The later author assigned a Lower-Middle Miocene age to the deposits of the Marádah Formation and divided it into a lower unit, namely Qárat Jahannam Member, and an upper unit, namely the Ar Ráhlah Member. The lithological boundary between the two members has been interpreted by the last author as diachronous and is the reflection of the change of facies due to the deposition in the Sirt Basin. Both units, however, are representing the clastic and the carbonate phases of Doust (1968) respectively.

The name of the type section of the Qárat Jahannam Member was derived by Maštera (1985) from the most residual hill, the Qárat Jahannam, in the southwestern Marádah Oasis. It is located along the road that connects Marádah to Zallah (see Figure 2). According to Selly (1969), the Qárat Jahannam Member is probably equivalent to Moghra Formation in Egypt (Said, 1962; 1990). Based on sedimentary structures and ichnofossil contents the Moghra Formation was deposited in a tidally-influenced fluvial environment (see Tawfik et al., 2018). The total thickness of the Qárat Jahannam Member is about $123 \mathrm{~m}$. and the rocks are dominated by whitish fine-grained, usually cross-bedded sands with sporadic laminae of 
claystone and siltstone. The lower contact with the underlying Oligocene sediments is disconformable while the upper contact with the Middle Miocene sediments of the overlying Ar Ráhlah Member is transitional (Maštera, 1985).

The name of the type section of the Ar Ráhlah Member, however, was also given by Maštera (1985), to a sequence located in the northeast of the Marádah Oasis where the escarpment is dissected by an asphaltic road. According to the Maštera (1985) the Ar Ráhlah Member is equivalent to the Ar Rajmah Group of Al Jabal al Akhdar area of northern Cyrenaica and the Marmarica Formation in Egypt (Said, 1962; 1990). The average thickness of the member is about $150 \mathrm{~m}$. and the rocks are dominated by fossiliferous creamy limestones and dolomites and subordinate intervals of claystone and other non-carbonate rocks. The lower boundary with the underlying Qárat Jahannam Member is gradual in most cases. The upper boundary with the overlying Wadi Yunis Member of the Al Khums Formation, however, is abrupt towards the northeast of the Marádah Oasis (Maštera, 1985).

\section{Results and Discussions}

\subsection{The Southwestern Outcrops}

The studied sequence at this locality is represented by section one (S1) and section two (S2) (Figure 5). They are located close to the type section, the Qárat Jahannam (see Figure 2). The total thickness of the studied sequence is up to $100 \mathrm{~m}$. and the stratigraphic succession is generally similar in both sections, the difference being only in the slight thickness variations of each lithological unit (i.e. facies) (see Figure 5).

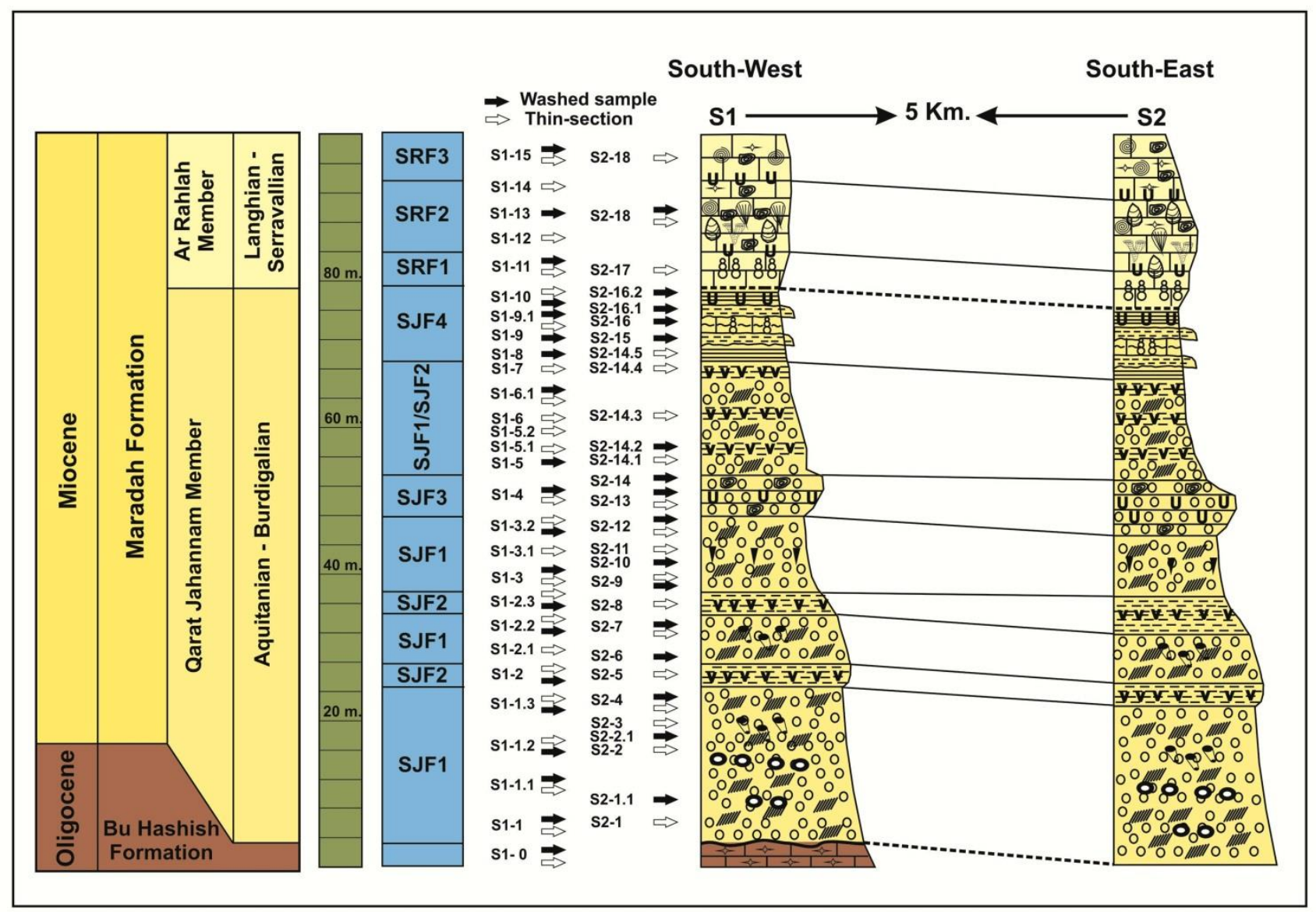

Figure 5. Stratigraphic characteristics of the Marádah Formation showing the different recognized facies (SJF1-SRF3) at the outcrop-scale and the correlation between section one (S1) and section two (S2) at the southwestern Marádah Oasis

It is worth noting, that the base of the Marádah Formation in this region rests on an erosional surface in section one (S1) above a $0.5 \mathrm{~m}$. thick of a nummulitic unit of the Oligocene Bu Hashish Formation (see Figure 5). The unit is showing wackestone texture under the microscope and is enriched by leached A-form Nummulites fichteli Michelotti, with other shell-fragments of bivalves and nummulitids (Plate 1, figures 1; 2). Normally, A-Form nummulites arise favorably when environmental conditions are optimal for growth (Reiss \& Hottinger, 1984). B-Form nummulites, however, are few both in thin-section and in hand specimen. The lack of abrasion and abundance of intact A- and B-forms witnesses in the study samples, reflect autochthonous to para-autochthonous accumulations of nummulites (Racey, 1995; 2001; Abdulsamad \& Tmalla, 2008). In the surrounding of the Qárat Jahannam, the nummulitic unit, however, is showing nummulites coquina 
and almost entirely made of A-Form Nummulites fichteli Michelotti (Figure 6). According to Maštera (1985), this unit is of several meters in thickness and extends for about $150 \mathrm{~km}$ in the surrounding region. It is interpreted by the later author to originate in the shallow marine environment of the inner shelf. The age of this unit, however, has been interpreted as Upper Oligocene (lower Chattian) by most workers in the region based on the occurrence of Nummulites fichteli Michelotti. As this species is well known from the Lower Oligocene (Rupelian) in the circum-Mediterranean region and in the neighborhood region of Cyrenaica (see Abdulsamad, 2000; Abdulsamad et al., 2009), the age of the Bu Hashish Formation has been revised by the current authors and will be discussed elsewhere.

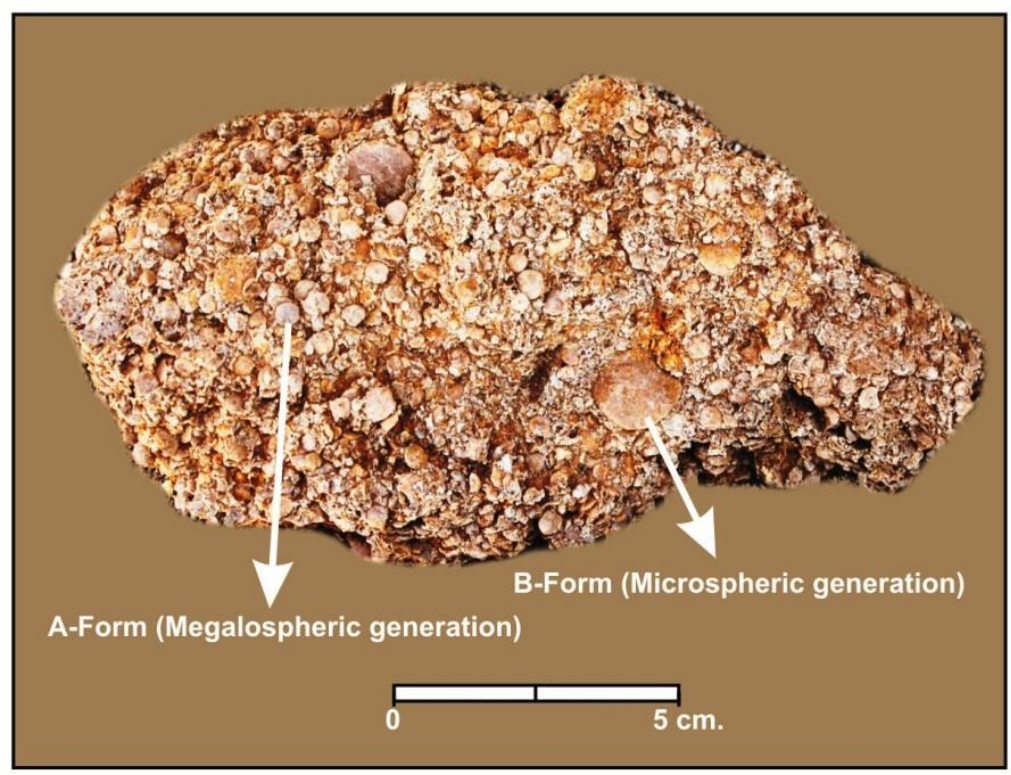

Figure 6. Show a sample of the nummulites coquina in the surrounding of the Qárat Jahannam. Note, although the

B-forms of the nummulites are present, the majority of the rock consists of A-Form Nummulites fichteli

In section two (S2), however, the contact is covered by the outwash of weathered sands from the overlying units (see Figure 3b).

The Marádah Formation at the southwestern outcrops (S1 and S2) is representing by the lower Qárat Jahannam Member and the upper Ar Ráhlah Member. Both units, however, are representing the so-called continental and the carbonate phases mentioned in earlier studies. The lower Qárat Jahannam Member interpreted to deposit in the Lower Miocene (Aquitanian-Burdigalian) based on its stratigraphic position in which rests unconformably on the Oligocene Bu Hashish Formation. The boundary between the lower Qárat Jahannam Member and the upper Ar Ráhlah Member, however, has been set based on a major facies change (see Figure 5) and supports by the recovery of the first aberrance of the larger benthic foraminifera Borelis melo melo (Fichtel \& Moll). The recovery of this subspecies from the washed residue and in thin-section indicates that the upper Ar Ráhlah Member at the southwestern outcrops is Middle Miocene (Langhian and Serravallian) in age. The attribution of the latter subspecies to the Middle Miocene is based on its overall spherical morphology in the Mediterranean region (see Adams, 1984). Yet based on the stratigraphic data provided by Jones et al. (2006), one can conclude that Borelis melo melo (Fichtel \& Moll) is abundant from the Middle Miocene deposits of the Mediterranean region, whereas this subspecies is infrequent from the Upper Miocene in the same region (e.g., Messinian of southeast Spain, Cabo de Gata, Province Almeria; see Betzler \& Schmitz, 1997). Borelis melo melo (Fichtel \& Moll) has been observed in Libya by Berggren (1967); by Sherif (1991) from the Middle Miocene Al Khums Formation (northwest Libya); by Abdulsamad et al. (2009) and more recently by Abdulsamad et al. (2018) from the coeval deposits in the neighboring coastal area of al Jabal al Akhdar of the northern Cyrenaica of NE Libya.

The Qárat Jahannam Member at the southwestern outcrops (S1 and S2) is about $80 \mathrm{~m}$ thick (see Figure 5) and primarily consists of four different facies (SJF1-SJF4) at the outcrop-scale. They are representing cyclic sedimentation for most of the measured sequence and are briefly described below in stratigraphic order.

Facies one (SJF1) is the dominant facies and representing about 75\% of the Qárat Jahannam Member. It principally consists of whitish-yellowish soft and fine-grained calcareous sands (Figure 7a; Plate 1, figure 3) interbedded with low angle and small scale cross-bedded sandstone (Figure $7 \mathrm{~b}$ ). The sandstone is poorly sorted, composed largely of subangular to subrounded quartz grains with a common detrital clay matrix (Plate 1, figure 4). At the outcrop-scale, this facies is associated with common reworked mammal bones, sharks-teeth, and silicified wood. The calcareous sands are 
interpreted by Selly (1969) to deposit in an estuarine environment whereas the cross-bedded sandstones are described by him as fluviatile in nature. As the two lithologies are often compositionally immature which reflect rapid deposition in subaerial environments, such as a river (Miall, 1985; 2006) and lack of any shelly fauna representing estuarine settings, we have grouped them under one facies (SJF1) and the whole sediments are considered here to deposit in a fluvial environment.

The overlying, facies two (SJF2) consists of claystone and is representing the second main lithology in the studded sequence. It represents about $15 \%$ of the total sediments of the Qárat Jahannam Member in this area. It is normally intercalated with facies one (SJF1) at upper levels where secondary gypsum patches are commonly found between the sandstones and the claystones (Figure 8a). At least two thick-bedded of claystone can be recognized at the lower levels. Herein, the claystone (Figure $8 b$ ) is yellowish in color, massive, and locally gypsified suggesting deposition in low-energy shoreline or lagoon. At the microfacies-level, the sediments are very fine-grained and regularly show homogenous composition (Plate 1, figure 5). At the top of the sequence, the claystone becomes laminated and may reflect quite a water of deposition (Figure 9a).

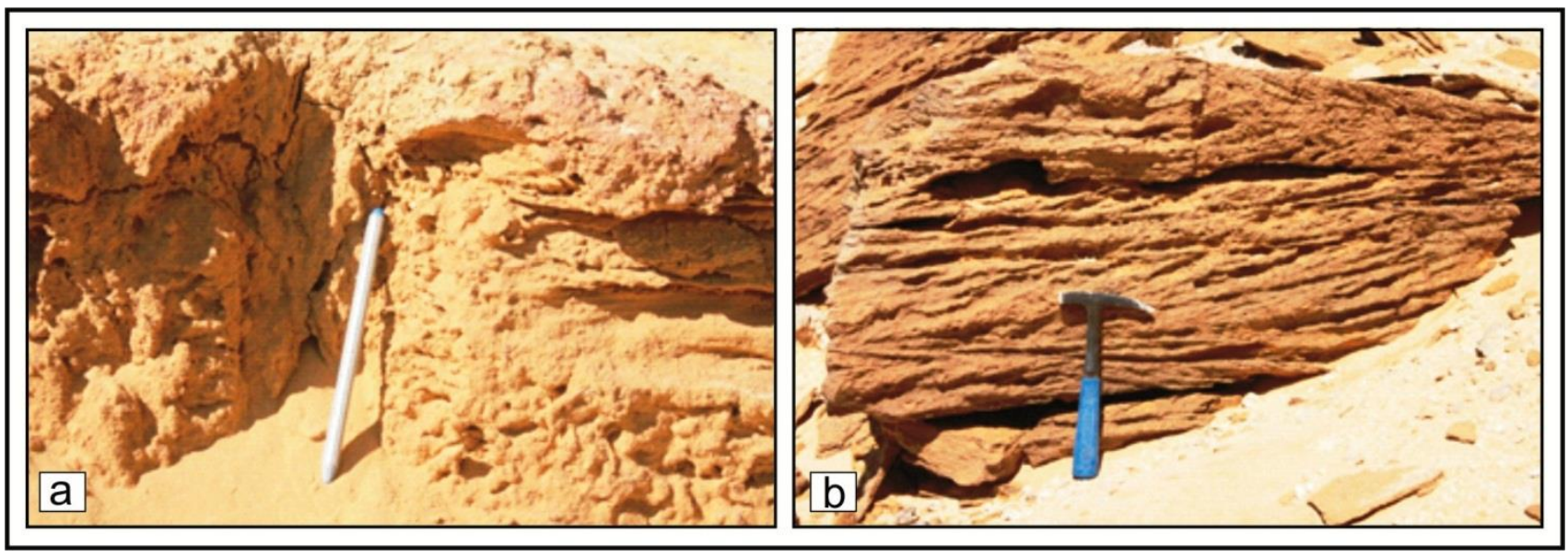

Figure 7. Views showing the calcareous sands (a), and the cross-bedded sandstone of the facies one (SJF1) (b) at the southwestern outcrops
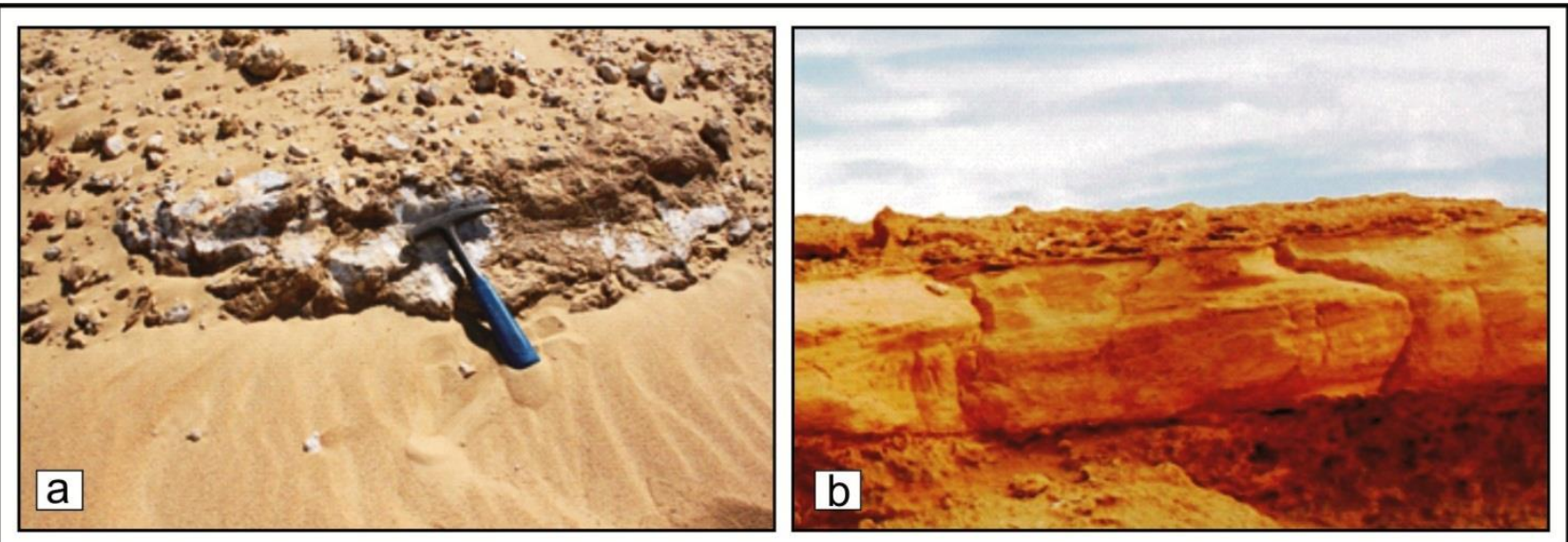

Figure 8. Views showing secondary gypsum (a), and a thick-bedded of yellowish claystone of facies two (SJF2) (b) at the southwestern outcrops

A reddish-brown thick-bedded of a bioturbated calcareous sandstone unit is representing the overlying facies three (SJF3). This facies is separating the lower and upper parts of the Qárat Jahannam Member in the studied sections (see Figures 3; 5). At the microfacies-level, the rock texture is largely fine-grained, poorly sorted with common large grains of quartz (Plate1, figure 6). The bedding, however, is largely disturbed by dwelling simple to complex burrow system (Figure 9b). Simple straight tubes (Skolithos), however, are representing the major contributors to the burrow system. Normally, Skolithos ichnofacies represent a marginal marine setting but may occur also in high-energy continental environments (Buatois et al., 1998; Melchor et al., 2003). Their associations with abraded small-sized pelecypods at this level, however, may indicate that the deposition was in sandy shoreline in very shallow depth with high-energy. 

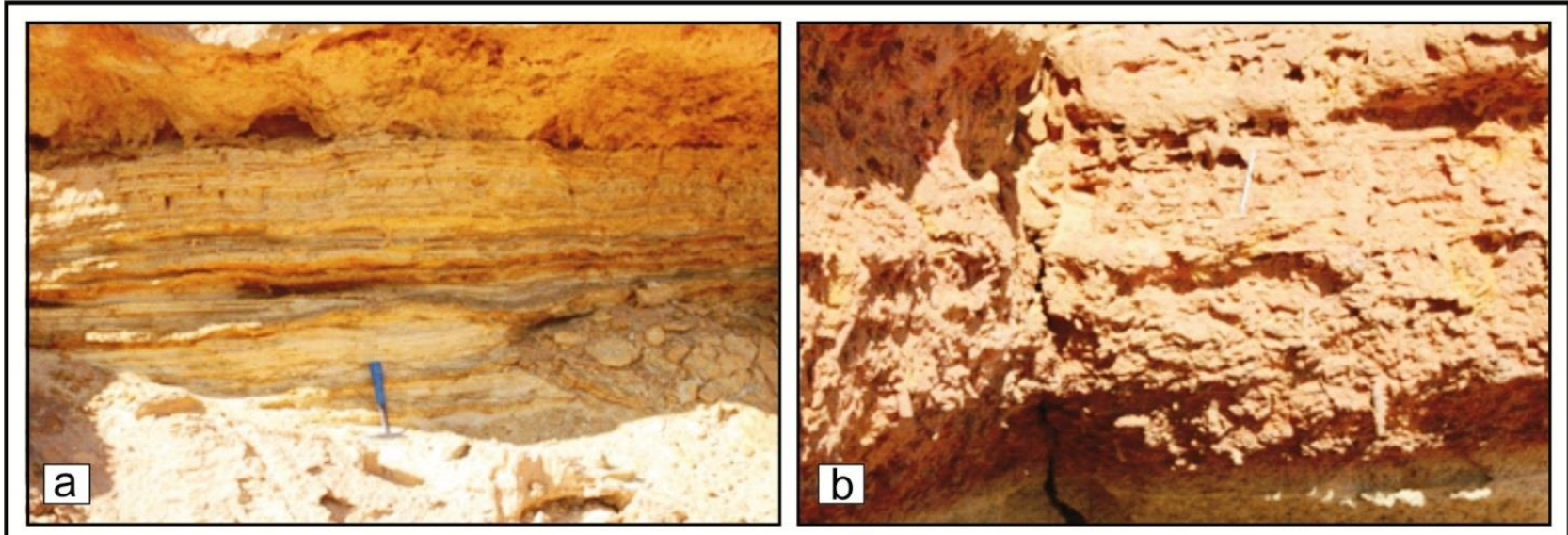

Figure 9. Views showing the laminated-claystone of facies two (SJF2) (a), and the bioturbated calcareous sandstone of facies three (SJF3) (b) at the southwestern outcrops

The reaming sediments of the Qárat Jahannam Member are representing by facies four (SJF4) (Figure 10a). Herein, the lithology is mainly dominated by yellowish-brown and green laminated calcareous shale interbedded with claystone similar in lithology to the claystone examined in facies two (SJF2). The claystone in this interval, however, is rarely gypsified and intercalated with laminae of silty marlstone enriched by small-sized internal casts of gastropods. The uppermost of this facies, however, is represented by thin-bedded of laminated calcareous shale and show subareal bioturbation by roots that infer deposition in river-floodplain or low-energy shoreline (Bentham et al., 1993). The laminated-shale, nevertheless, is interpreted by Selly (1969) as Lagoon.
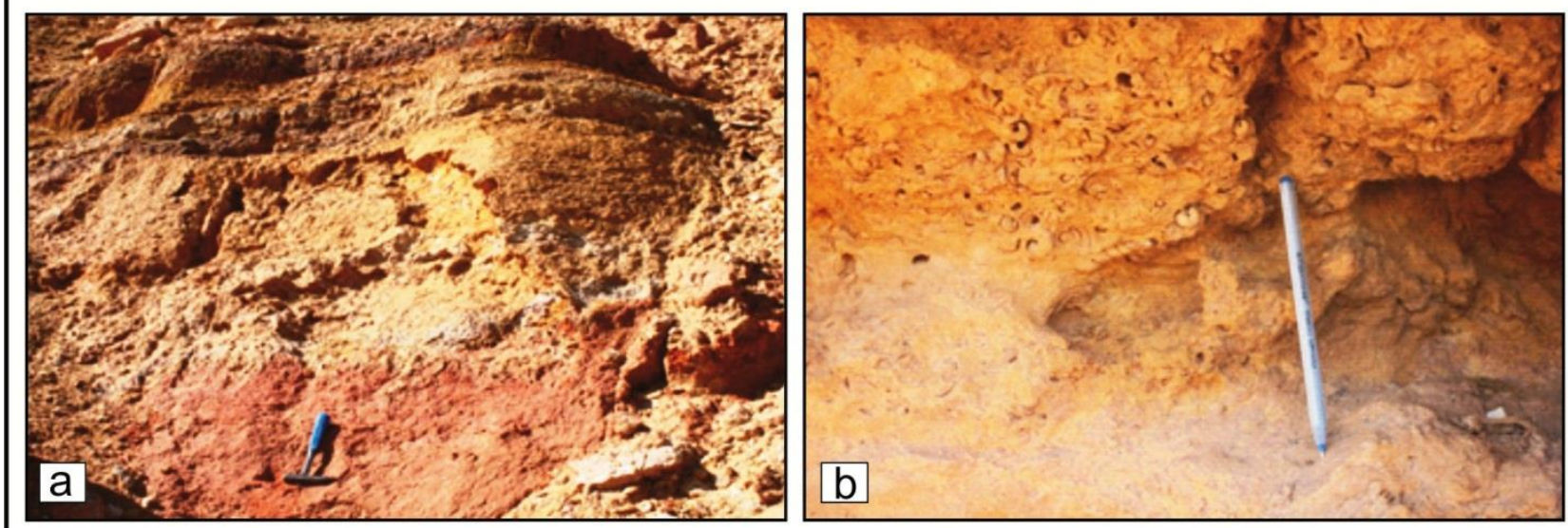

Figure 10. View displays the laminated calcareous shale intercalated with claystone and silty marlstone of the facies four

(SJF4) of the Qarat Jahannam Member (a). A view shows the gastropoda bed of facies one (SRF1) of the Ar Ráhlah Member (b)

The overlying Ar Rahlah Member in this locality is about $20 \mathrm{~m}$ thick in both studied sections and mainly consists of three distinct facies (SRF1-SRF3). The first facies (SRF1) is observed on the base above the contact with the underlying Qárat Jahannam Member. Herein, the lithology is represented by whitish to yellowish detrital limestone which is composed largely of cemented shell-fragments. At the microfacies-level, the sediments at both study sections are mostly showing grainstone texture although mud-supported wackestone-texture with common micrite-clasts is locally observed (Plate 2, figures 1;2). In section two (S2), the washed residue of the detrital limestone contain poorly preserved specimens of Borelis melo melo (Fichtel \& Moll), nonetheless, the facies show low-angle stratification and terminated by a gastropod bed at the outcrop-scale (Figure 10b). The gastropods, however, are largely represented by large-sized suspension feeder species of Turritellids which indices shallow nearshore conditions (Pashko, 2018). As the assemblage of gastropods include other biconical and trochiform forms which are often abraded because of transport and sorting the accumulation of facies one (SRF1) is interpreted here to deposit in high-energy environments like beaches or raised banks.

The overlying facies two (SRF2) of the Ar Rahlah Member is whitish to reddish bioclastic limestone rich in thick-oysters (notably, Crassostrea gryphoides (Schlottheim)) at the outcrop-scale (Figure 11a). Such oysters are normally a dweller adapted to shallow-marine towards estuarine intertidal environments (Harzhauzer et.al, 2016) but as all the recovered 
specimens were disarticulated, which reflect transportation under high-energy conditions, a different habitat such as shoreline environment is further reliable. Their association with celestite corals, bryozoans, and small-sized and thick bivalves may provide supporting evidence. At the microfacies-level, the sediments are showing a packstone-grainstone texture with common shell-fragments of bivalves, and bryozoans (Plate 2, figures 3; 4). A temperate bioturbation rate by burrowing, however, has been recognized and characterizes the lower and upper limits of this facies at the outcrop-scale which may infer a sandy shore environment of deposition (see Figure 5).

Up-section, the studied sequence is terminated with facies three (SRF3) which consists of white and fairly firm limestone (Figure 11b). Here, few thick and large-sized sublittoral inhabitant gastropods Turritella and Conus are recovered and documented as indices nearshore environments (Harzhauzer, 2004; Wielandt-Schuster et al., 2004). The overall lithology, however, is quite distinguishable by its tiny and fragmented shelly aberrance which provides further evidence for a nearshore environment with similar water energy seen in the underlying facies (SRF2). At the microfacies-level, the sediments are showing mostly wackestone-texture with sparsely fossiliferous micrite clasts. It includes shell-fragments of bryozoans, and Borelis melo melo (Fichtel \& Moll) (Plate 2, figures 5; 6). The lowermost part of facies three (SRF3), however, is representing modest bioturbation by simple straight tubes and burrows whereas the uppermost part is massive and has been extensively used by the local community for industrial purposes.
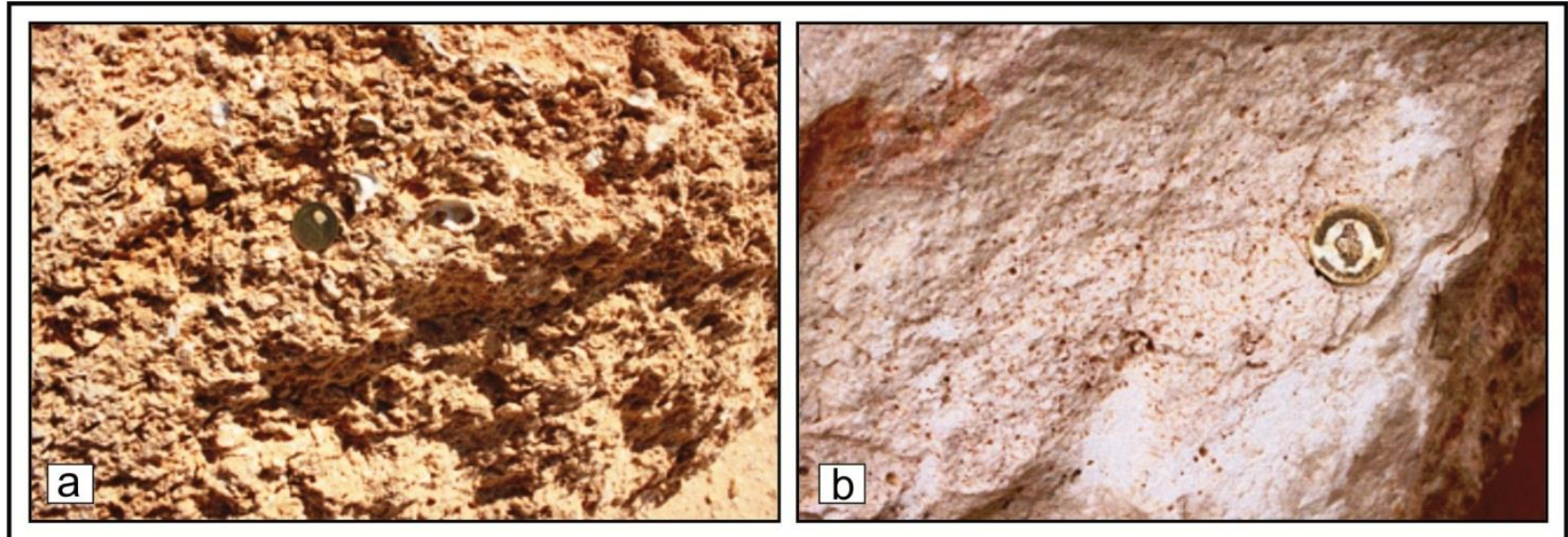

Figure 11. Views showing the detrital limestone with common oysters of the facies two (SRF2) at section two (S2) (a), and the white limestone with shell-fragments of facies three (SRF3) of the Ar Ráhlah Member at section one (S1) (b) 


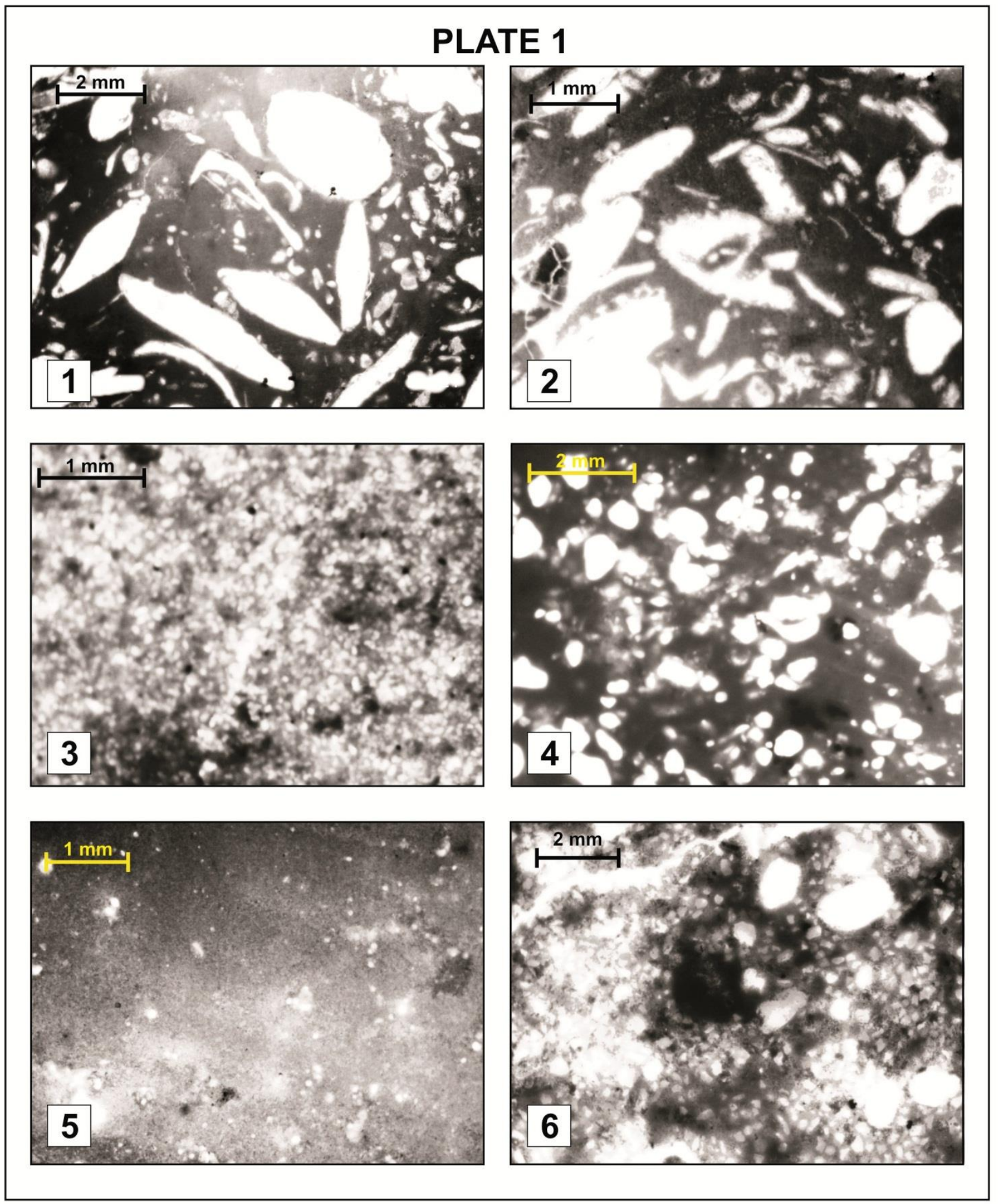

Plate 1. Figures 1; 2. Photomicrographs show mud-supported wackestone of the Oligocene Bu Hashish Formation. The sediments are enriched by leached A-form Nummulites fichteli Michelotti, with other shell-fragments of bivalves and nummulitids. Figures 3; 4. Photomicrographs showing facies one (SJF1) of the Qárat Jahannam Member of the Marádah Formation, which consists largely of fine-grained calcareous sands (figure 3) interbedded with poorly sorted sandstone (figure 4). The latter texture is made mostly of subangular to subrounded quartz grains and common detrital clay matrix. Figure 5. Photomicrograph showing facies two (SJF2) of the Qárat Jahannam Member of the Marádah Formation, which consists of claystone. The sediments are very fine-grained, and more than half of the composition is showing clay-sized 
particles. Figure 6. Photomicrograph showing facies three (SJF3) of the Qárat Jahannam Member of the Marádah Formation, which consists of calcareous sandstone. The rock texture is composed mostly of fine-grained, poorly sorted with common large grains of quartz.

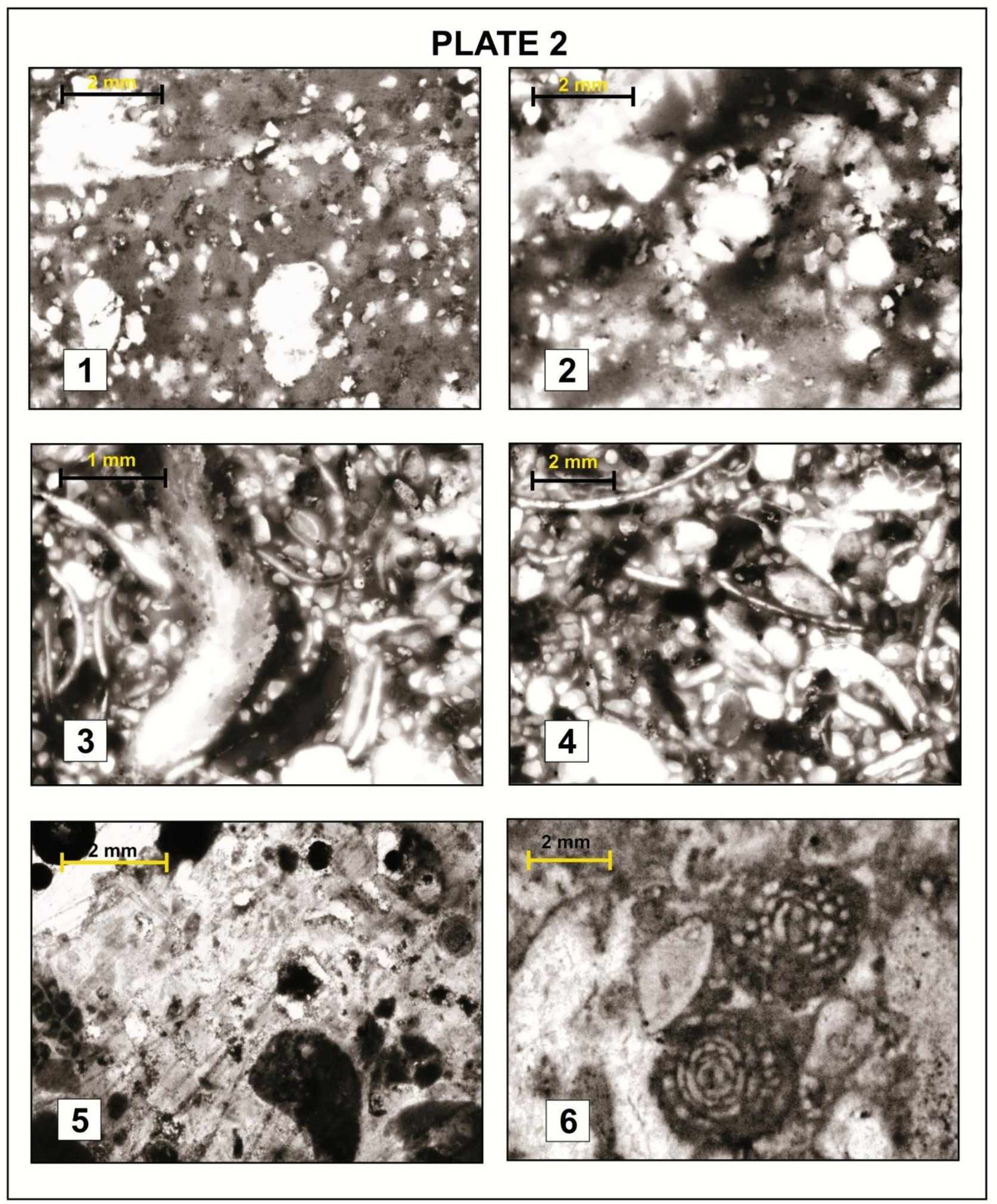

Plate 2. Figures 1; 2. Photomicrographs showing facies one (SRF1) of the Ar Rahlah Member of the Marádah Formation, which consists mostly of mud-supported wackestone-texture with common micrite-clasts and large shell-fragments of bivalves. Figures 3; 4. Photomicrographs showing facies two (SRF2) of the Ar Rahlah Member of the Marádah Formation, 
which consists of bioclastic limestone. The sediments are showing a packstone-grainstone texture with common Shell-fragments of bivalves and a large fragment of bryozoa (Figure 3). Figures 5; 6. Photomicrographs showing facies three (SRF3) of the Ar Rahlah Member of the Marádah Formation, which consists mostly of wackestone-texture with sparsely fossiliferous micrite clasts. It also includes shell-fragments of bryozoans and Borelis melo melo (Fichtel \& Moll) (Figure 6).

\subsection{The Northern Outcrops}

The studied sequence at this locality is represented by section three (S3) and section four (S4) (Figure 12). They are representing by two different residual hills located in the northern part of the Marádah Oasis (see Figure 2). The total thickness of the studied sequence is about $80 \mathrm{~m}$. and the Marádah Formation is represented here only by the upper member, namely the Ar Ráhlah Member. Apart from the uppermost facies (NRF7) which is present only in section three (S3), the stratigraphic successions are generally similar, the difference being only in the slight thickness variations of each individual lithological unit (i.e. facies). The lower and upper contacts of this member with the underlying Qárat Jahannam Member of the Marádah Formation and the overlying Wadi Yunis Member of the Al Khums Formation are not recognized in these localities. The upper contact, however, can be recognized in Qárat ash Shih, further north near Sidi Tahabit along the road to Al Brega (see Figure 2). Herein, the lower unit of the Wadi Yunis Member is consisting of quite hard gypsiferous limestone rests unconformably over a soft unit of dolomitic marly limestone of the Ar Ráhlah Member of the Marádah Formation (Figure 13a). Large internal casts of oysters (notably, Crassostrea gryphoides) are recovered from the dolomitic marly limestone unit below the contact (Figure 13b) whereas large-sized internal gypsified casts of gastropods (notably, Conus sp. and Turritella sp.) and pelecypods (essentially, Codakia lionina (Basterot)) are recovered from the overlying limestone (Figure 14).

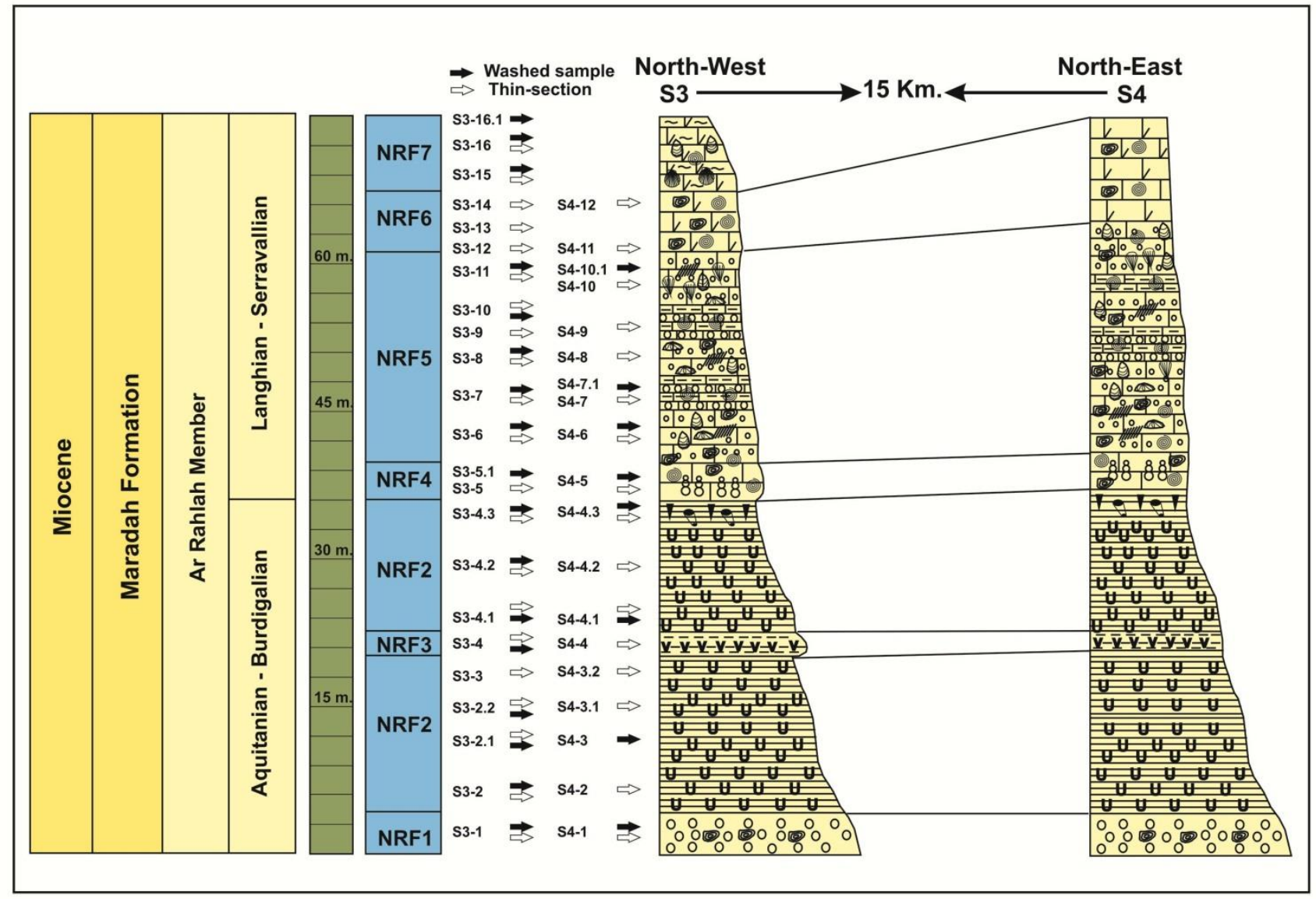

Figure 12. Stratigraphic characteristics of the Ar Ráhlah Member of the Marádah Formation showing the different recognized facies (NRF1-NRF7) at the outcrop-scale and the correlation between section three (S3), and section four (S4) at the northern Marádah Oasis 

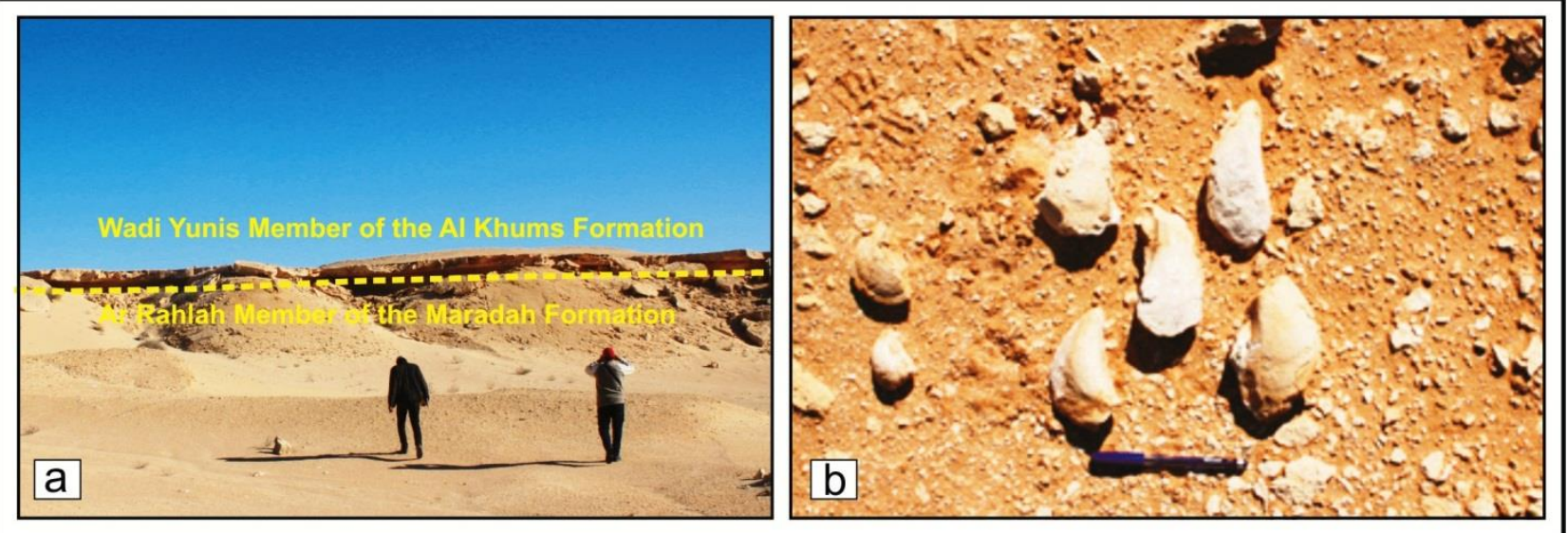

Figure 13. View showing the contact between the Ar Ráhlah Member of the Marádah Formation and the overlying Wadi Yunis Member of the Al Khums Formation near Sidi Tahabit (a). Large internal casts of Crassostrea gryphoides, which recovered from the uppermost unit of Ar Ráhlah Member of the Marádah Formation near Sidi Tahabit (b)
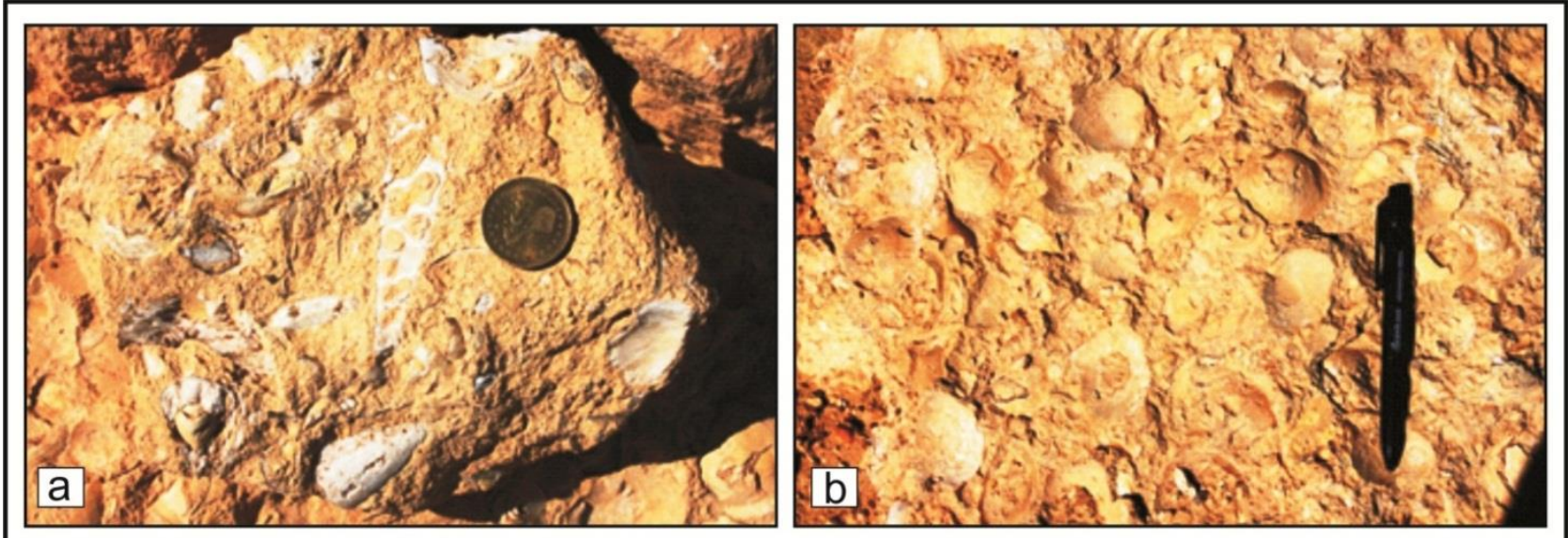

Figure 14. Views of internal gypsified casts of turreted and biconical gastropods (a), and internal and external castes of Codakia lionina (b), which recovered from the overlying limestone unit of the Wadi Yunis Member of the Al Khums

Formation near Sidi Tahabit

The Ar Ráhlah Member of the Marádah Formation at the northern outcrops, however, is represented by seven different facies (NRF1-NRF7). Herein, the lower part of Ar Ráhlah Member is denoted by NRF1-NRF3 which primarily resembles the continental-dominated phase mentioned above and consequentially the sediments have been assigned to the Lower Miocene (Aquitanian-Burdigalian). The overlying facies (NRF4-NRF7), nevertheless, are corresponding to the carbonate-dominated phase in the region and the deposits have been attributed to the Middle Miocene (Langhian and Serravallian) based on the total-stratigraphic range of Borelis melo melo (Fichtel \& Moll), which recovered from the washed residues at both studied sections (S3 and S4). Below, however, a brief description of the main recognized facies is presented in stratigraphic order.

Facies one (NRF1) is representing the base of the Ar Ráhlah Member of the Marádah Formation in these localities (see Figure 12). It consists of whitish-yellowish calcareous sands and sandstones similar in aberrance to the calcareous sands and sandstones facies (SJF1) present at the southern outcrops (S1 and S2) (see Figure 5). Facies one (NRF1) at these localities, however, is mostly representing by fine calcareous sands at the microfacies-level (Plate 3, figure 1) but includes fragmented marine organisms such as pelecypods and rare but regular occurrences of vertical bioturbation structures at the outcrop level. Such characteristics are consistent with estuarine settings where substrate shifting and fluctuations in turbidity and salinity are common (Frey \& Howard, 1986; Buatois et al., 2002). A similar facies in the neighborhood region, however, has been interpreted to deposit in estuarine channel mouths and on the edges of the lagoons by Savage and white (1965). Moreover, the latter facies is reported to increases considerably in thickness toward the east and are considered by many authors (e.g., El Hawat, 1980) as the lowermost part of the Marádah Formation (i.e. the Qárat Jahannam Member). Based on stratigraphic criteria and the lack of an erosional surface separating facies one (NRF1) 
from the overlying facies two (NRF2), the current survey, nevertheless, is considered the facies one (NRF1) as the base of the Ar Ráhlah Member of the Marádah Formation.

Up-levels, the sequence considerably consists of facies two (NRF2) where conspicuous yellowish-green laminated-shale represents about $50 \%$ of the total sequence. Unlike, the laminated calcareous shale (SJF4) examined from the uppermost part of the Qárat Jahannam Member in the southwestern outcrops (see Figure 5); the laminated-shale in the northern outcrops (see Figure 12) is very distinct, very thick, and extremely bioturbated (Figure 15). Herein, the bedding is extensively disturbed by a complex burrow system. Simple vertical tubes such as Skolithos and burrows with pelleted walls such as Ophiomorpha are the major contributors to the burrow system. Branching dwelling burrows such as Thalassinoides, however, are faint and infrequently perceived. The vertical trace fossil assemblage (Ophiomorpha, Skolithos) is indicative of the Skolithos ichnofacies of Seilacher $(1967 ; 2007)$ which corresponds to the beach, foreshore, and shoreface with high-energy levels (Frey et al., 1990). The lithological features of the studied Ophiomorpha, however, suggest that the trace-makers preferentially colonized high-energy sand environments (Nagy et al., 2016). Microfacies associated with this interval, though, are mostly showing fine-grained sand texture with common quartz and irregular skeletal grains (Plate 3, figure 2) which suggest that the total sediments of facies two (NRF2), were deposited in the sublittoral zone with high-energy (NRF2).

Up-sequence, the laminated calcareous shale (NRF2) is intercalated by facies three (NRF3) which is representing by a thick-bedded of fine-grained and gypsiferous yellowish claystone (see Figure 12). The latter facies (NRF3) is similar to facies two (SJF2) which is examined in the southern outcrops at the outcrop-scale (see Figure 5). At the microfacies-level, conversely, the texture of the rock show quite sub-rounded detrital quartz sand grains which display deposition in the low-energy shoreline or lagoonal setting (Plate 3, figure 3). It is worth noting, however, that the separation between the laminated calcareous shale facies (NRF2) and gypsiferous yellowish claystone (NRF3) is not possible in several places at the northeastern part of the Marádah Oasis which led some authors in the area to treat them as a single facies. The absence of body and trace fossils in facies three (NRF3) and the occurrence of a large amount of gypsum in the northeastern area led Selley (1966) to suggest that this facies has been deposited in a restricted lagoonal environment.

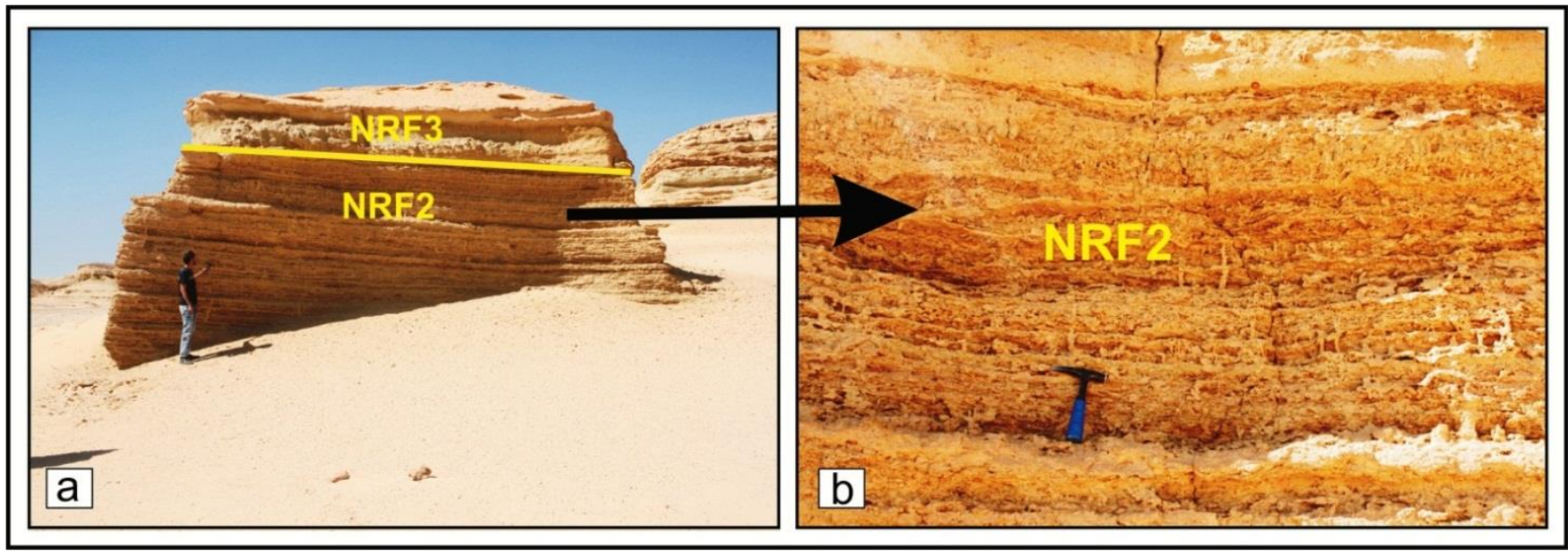

Figure 15. Views from section three (S3) at the northern outcrops. (a) A slump-block showing yellowish-green laminated-shale (NRF2) overlying by yellowish and fine-grained claystone (NRF3) of the Ar Ráhlah Member of the Marádah Formation. (b) A close-up view of the laminated-shale facies (NRF2) showing a complex burrowing system

The overlying facies four (NRF4) is represented by a whitish-yellowish detrital limestone bed rich in a diverse assemblage of gastropods (Figure 16). This facies resembles facies one (SRF1) examined in the southwestern outcrops (see Figure 5). The gastropods in this locality, however, are chiefly represented by high-spired turreted with scarce biconical and trochiform tests. Present-day mass occurrences of turritelline gastropods are occurring world-wide from shallower to deeper seas (0-1500 m. water-depth, more typically 10-100 m). They are suspension feeders and their mass occurrences usually occur in shallow-subtidal, siliciclastic environments rich in nutrients due to upwelling (see Rasser \& Nebelsick, 2007). As the turritelline gastropods are often found abraded in this interval, it may suggest accumulation in high-energy environments like beaches. The washed residue from this interval, nevertheless, contains numerous miliolids with infrequent Borelis melo melo (Fichtel \& Moll) which may support an open-shelf setting down to a water depth of a few dozen meters water (Abdulsamad et al., 2018). 


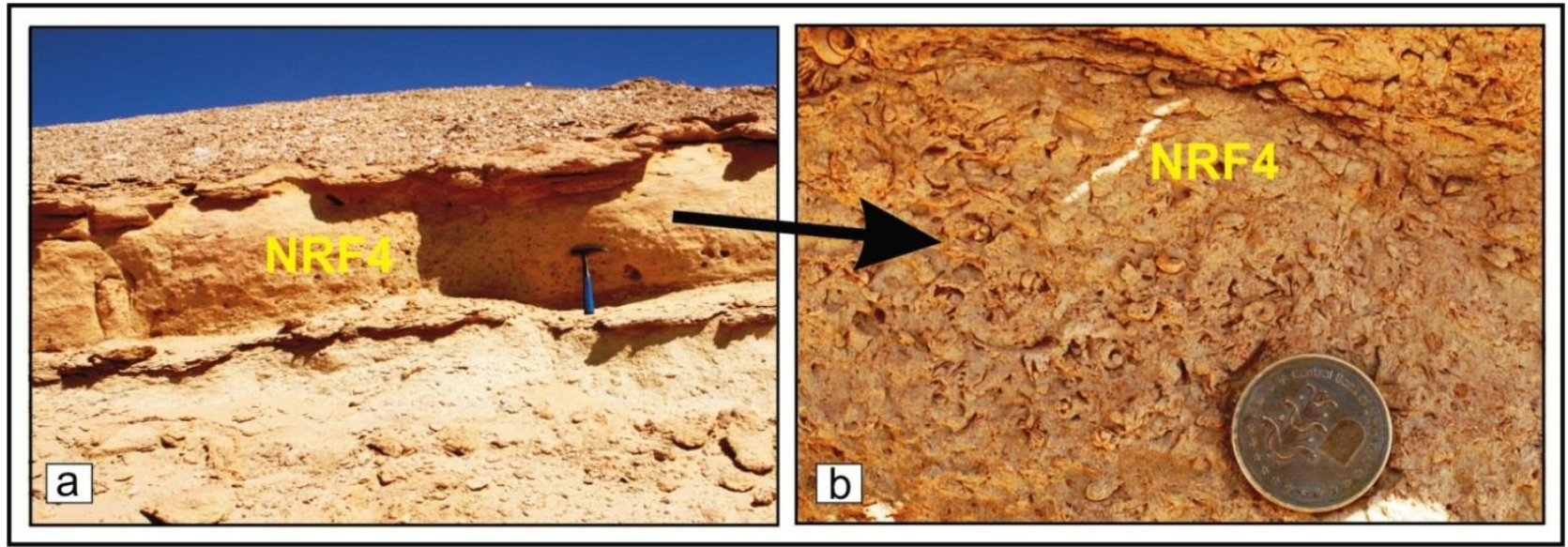

Figure 16. Views from section three (S3) showing the detrital limestone bed (NRF4) of the Ar Ráhlah Member (a). A close-up view shows a concentration of diverse assemblage of gastropods (b)

Up-sequence, the Ar Ráhlah Member is representing by facies five (NRF5) which consists of thick-bedded and whitish-reddish calcarenites (Figure 17a). Low-angle cross-bedding is normally associated with this facies particularly at the upper levels of section three (S3). Steeply-dipping cross-bedding which is reported in some local literature is not found in the current study. The studied facies is representing the main lithology of the upper part of the studied member in the northern outcrops. It is intercalated, however, in the middle part, with thin-bedded of sandy limestone and chalky limestone (see Figure 12). The overall unit, however, is quite fossiliferous and the primary lithology (the calcarenites) can be described as packstone-grainstone (Plate 3, figures 4; 5). Fossils, at the outcrop-scale, are diverse throughout facies five (NRF5) nonetheless irregular echinoids (notably, Clypeaster and Echinolampas) are representing the main fossil group and deduce deposition in a littoral-sublittoral environment (Mancosu \& Nebelsick, 2016). Recent counterparts of Clypeaster and Echinolampas, however, are now live in shallow and warm waters regions including the Red Sea (Ali, 2014). Medium-sized disarticulated oysters, gastropods, and celestite corals (Figure 17b) are subordinate and normally thrive in shallow and warm waters. The common occurrence of these body fossils concerning the lower part of the formation probably reveals a gradual change of sedimentation from a continental clastic to transitional estuarine, lagoon, and beaches to the proximal offshore (NRF5). This facies, though, has been interpreted by Selly (1966) to deposit in the offshore bar.
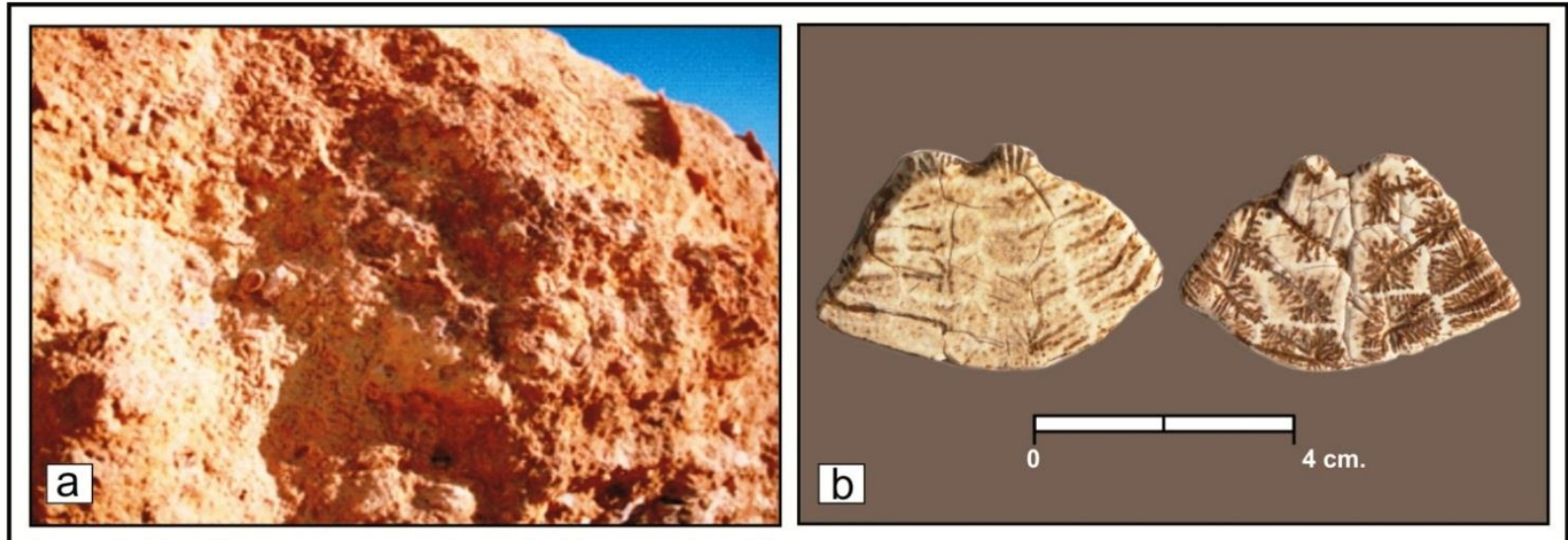

Figure 17. Views of whitish-yellowish calcarenites of facies five (NRF5) of the Ar Ráhlah Member (a), with fragments of celestite corals (b) recovered from section three (S3)

Up-levels, the Ar Ráhlah Member is terminated by facies six (NRF6) at section four (S4) that is represented by a rather hard dolomitic limestone unit (see Figure 12). Here, the lithoclasts are commonly re-crystallized, whereas the bioclasts are entirely leached-out. Only abraded pelecypods were recovered at the outcrop-scale and may indicate a nearshore or shoreface environment.

Facies seven (NRF7), however, is present in section three (S3) only and primarily consists of rather soft dolomitic marly limestone. Petrographic thin-sections associated with this level, show mud-supported wackestone texture with infrequent particles of clay and fine silt-size (Plate 3, figure 6). This facies is considered here as the last deposited unit of the Ar 
Ráhlah Member of the Marádah Formation since it has been found under the contact with the overlying Wadi Yunis Member of the Al Khums Formation near Sidi Tahabit as previously mentioned. It is also developed along the road to Al Brega (Figure 18a) but the overlying Wadi Yunis Member of the Al Khums Formation is missing. This facies in this locality is combined with in situ Ostreidae community including Ostrea digitalina Fuchs, along the road to Al Brega (Figure 18b). The recent relatives of this species, however, are typical in shallow coastal waters down to the $10 \mathrm{~m}$ water depth (Milisic, 1991; Mandic \& Harzhauser, 2003). Commonly, these oysters may indicate a relatively low salinity possibly due to a local and temporary influence of freshwater supply, which also caused the contamination by terrigenous quartz grains (see Abdulsamad \& El Zanati, 2013).
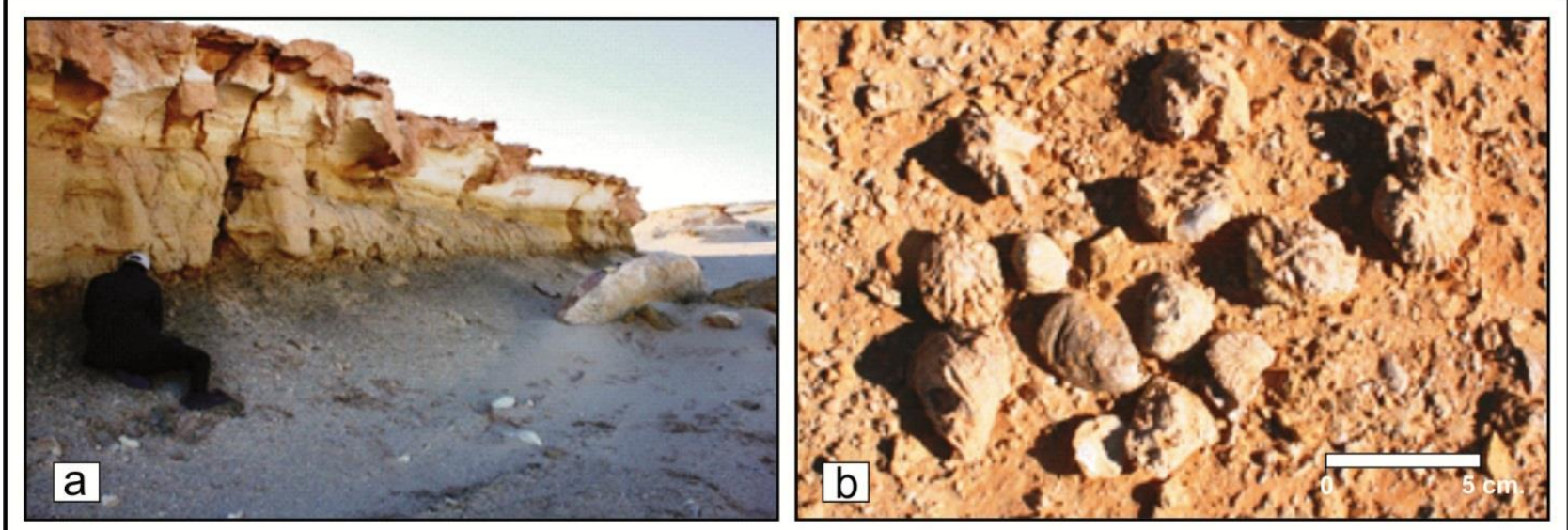

Figure 18. Views shows a quite soft dolomitic marly limestone stone of facies seven (NRF7) (a), and a collection of disarticulated oysters from the same lithological unit exposed along the road to Al Brega (b)

In section three (S3), however, large-sized oysters including Crassostrea gryphoides are associated with disarticulated pectinid bivalves at the top of the studied section (Figure 19) which display shallow-marine towards estuarine intertidal (littoral) environments (Harzhauzer et al., 2016). The recovery of poorly preserved miliolids including Quinquloculina and alveolinids (Borelis) from the washed residue, however, may suggest a deeper sublittoral condition (see Abdulsamad \& El Zanati, 2013) for facies seven (NRF7).
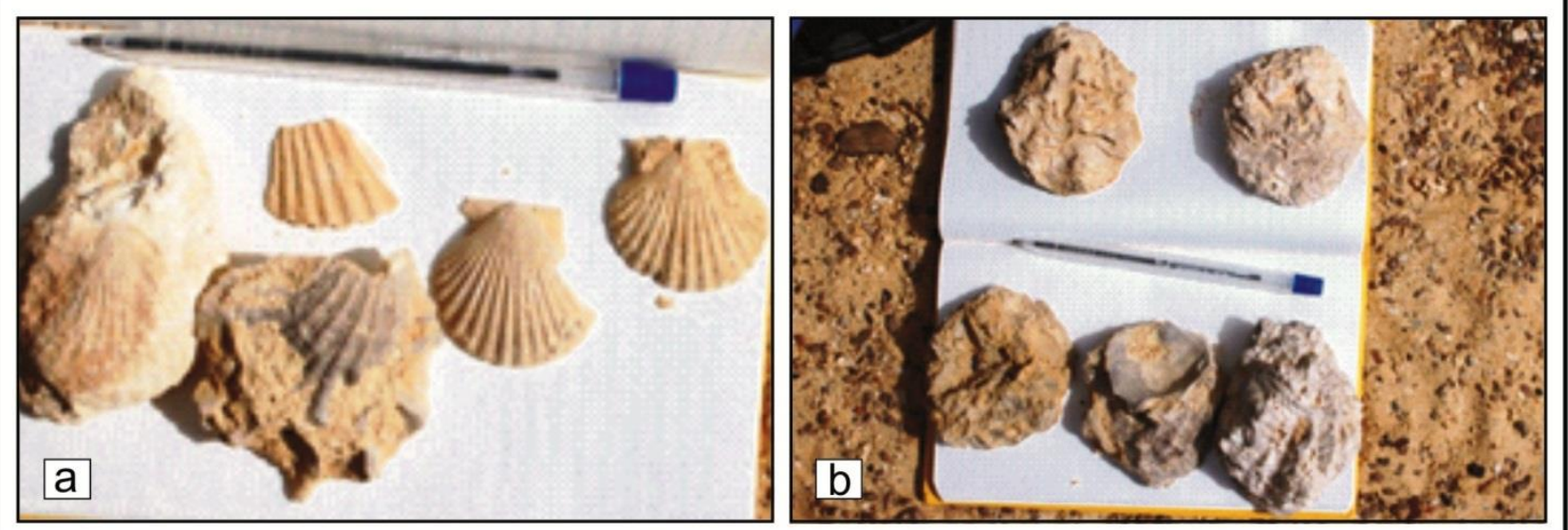

Figure 19. Views of pectininid bivalves (a), and large-sized oysters collected at the top of facies seven (NRF7) of the Ar Ráhlah Member at section (S3) 


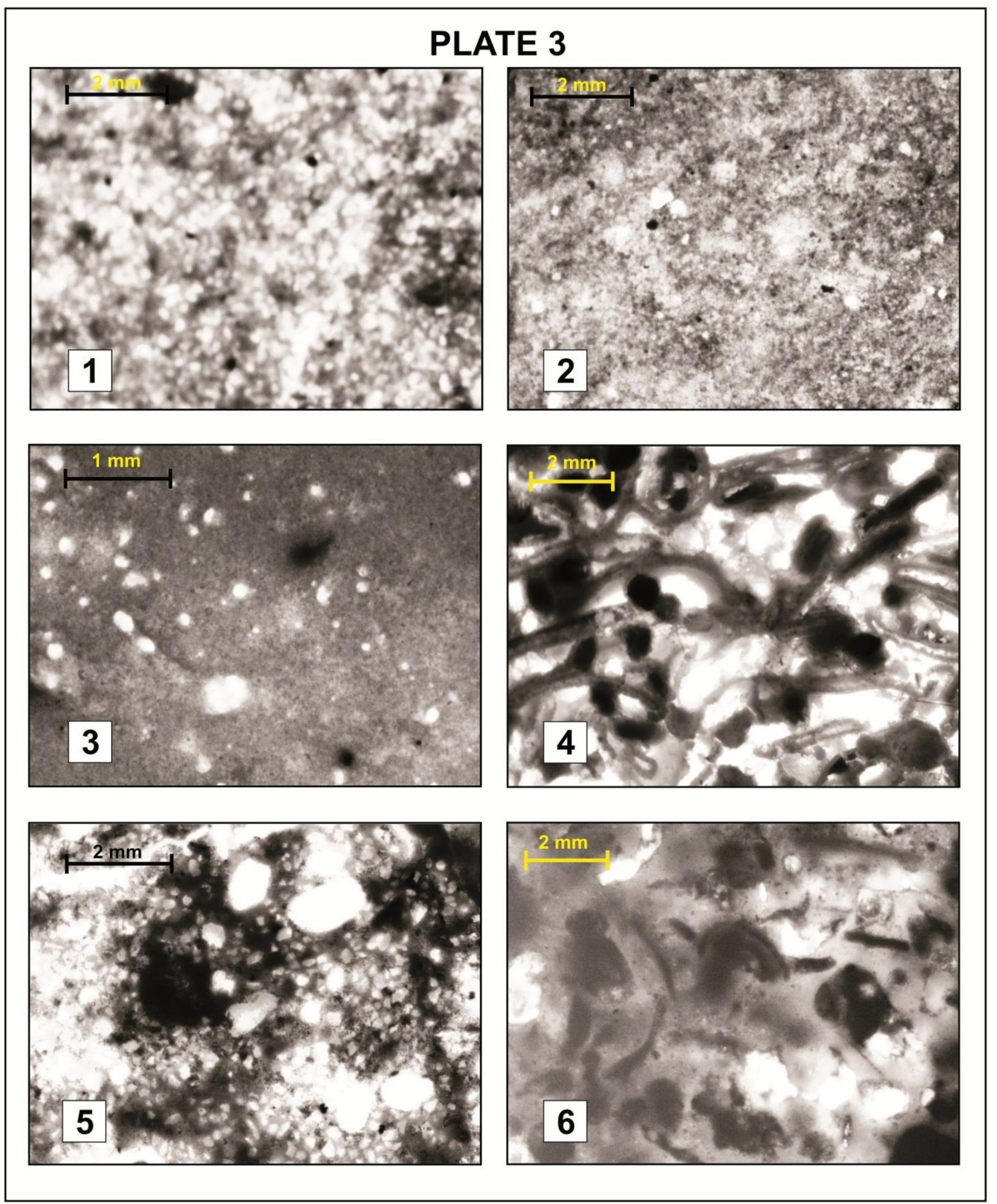

Plate 3. Figure 1. Photomicrograph showing facies one (NRF1) of the Ar Rahlah Member of the Marádah Formation, which is represented by fine calcareous sands with mutual micrite-clasts and sparsely shell-fragments of bivalves. Black areas are representing iron-oxide impregnation. Figure 2. Photomicrograph showing facies two (NRF2) of the Ar Rahlah Member of the Marádah Formation, which is denoted by fine-grained sand texture, common quartz, and rare skeletal grains. Figure 3. Photomicrograph showing facies three (NRF3) of the Ar Rahlah Member of the Marádah Formation, which consists of fine-grained claystone with common sub-rounded detrital quartz sand grains. Figures $4 ; 5$. Photomicrographs showing facies five (NRF5) of the Ar Rahlah Member of the Marádah Formation, which is represented 
mostly by skeletal limestone (notably, bivalves) with common detrital sand-size (calcarenites) carbonate grains (Figure 4). Particles of clay and fine silt-size are also present (Figure 5). Figure 6. Photomicrograph showing facies seven (NRF7) of the Ar Rahlah Member of the Marádah Formation, which is represented by mud-supported wackestone texture with occasional particles of clay and fine silt-size. Shell-fragments of bivalves are also present.

\section{Summary and Conclusions}

Four stratigraphic sections of the Lower-Middle Miocene Marádah Formation were measured and systematically sampled. The first and second sections (S1 and S2) are up to $100 \mathrm{~m}$ in thickness and were measured at the southwestern side of the Marádah Oasis. The majority of the sequence in this locality is considered here to represent the Qarat Jahannam Member which corresponds to the continental-dominated facies reported in the earlier studies. Both sections (S1 and S2), however, encompass four different facies (SJF1-SJF4) at the outcrop-scale. In stratigraphic order, their lithology is dominated by fine-grained calcareous sands interbedded with cross-bedded sandstone grading to gypsified claystone at the lower and middle levels and by bioturbated calcareous sandstone and laminated calcareous shale at the upper levels. Their depositional environment, though, is ranging from the fluviatile environment (SJF1), low-energy shoreline or lagoon setting (SJF2), high-energy sandy shoreline (SJF3) and river-floodplain, or low-energy shoreline (SJF4) respectively.

The reaming sediments of the S1 and S2 are considered here to represent the Ar Ráhlah Member which corresponds to the marine-dominated facies described in the previous studies. Herein, three different facies have been recognized at the outcrop-scale (SRF1-SRF3). The associated macrofauna at the base is mostly represented by common high-spired turreted and subordinate biconical and trochiform gastropods. They are often abraded because of transport and sorting and may suggest that the accumulation was in high-energy environments like beaches or raised banks (SRF1). The overlying facies, though, is represented by a bioclastic limestone unit rich in thick and disarticulated oysters (notably, Crassostrea gryphoides (Schlottheim) which infer transportation under high-energy conditions in a sandy shore environment (SRF2). Up-section, the studied sequence of the Ar Ráhlah Member is terminated by limestone unit rich in tiny shell-fragments of bryozoans and pelecypods and indicates a nearshore environment (SRF3) with similar water energy seen in the underlying facies.

The third and fourth sections (S3 and S4) are representing by two different residual hills located in the northern part of the Marádah Oasis. The total thickness of the studied sequence in this locality is about $80 \mathrm{~m}$. and the Marádah Formation is represented here only by the upper member namely, Ar Ráhlah Member. Herein, the studied sequence includes seven different facies (NRF1-NRF7). At the base, lithology is representing mostly by fine calcareous sands but includes some remains of marine organisms including abraded undersized pelecypods at outcrop-level which infer free connection with the open sea and indicates deposition in an estuarine environment (NRF1). Up-levels, the sequence is considerably consisting of highly bioturbated laminated-shale which represents about $50 \%$ of the total sequence. Herein, a vertical trace fossil assemblage (Ophiomorpha, Skolithos) shows Skolithos ichnofacies which correspond to the beach, foreshore, and shoreface zone. Microfacies associated with this interval, however, are mostly showing fine-grained sand texture with common quartz and rare skeletal grains and indicate that the overall deposition was in the sublittoral zone with high-energy (NRF2). Up-sequence, the laminated calcareous shale is intercalated by a thick-bedded of fine-grained and gypsiferous claystone. The texture of the rock show quite sub-rounded detrital quartz sand grains, which display deposition in the low-energy shoreline or lagoonal setting (NRF3). The overlying interval is regularly represented by a detrital limestone unit rich in turritelline gastropods which are often found abraded and suggesting accumulation in high-energy environments like beaches (NRF4). Up-sequence, the member is principally consisting of thick-bedded of calcarenites (NRF5). Fossils, at the outcrop-scale, are common and diverse throughout this interval and include disarticulated oysters, gastropods, echinoids, bryozoans, and celestite corals. The common occurrence of these fossils with respect to the lower part of the Marádah Formation probably reveals a gradual change of sedimentation from a continental clastic witness in southwestern outcrops (S1 and S2) to transitional estuarine, lagoonal and beaches to the proximal offshore in the northern outcrops (S3 and S4). The sequence of the Ar Ráhlah Member is terminated by quite a hard dolomitic limestone unit (NRF6) at S4 and by soft dolomitic marly limestone (NRF7) at S3. Both facies, however, are combined with medium-sized oysters (including Ostrea digitalina Fuchs) and pectinid bivalves, which display a warm, shallow, marginal marine environment of deposition.

Biostratigraphic calibration for the age of the studied formation is difficult due to the lack of identified age-diagnostic microfossils. The fact that much of the studied deposits consist of siliciclastic intervals which have no age-constraining microfossils is a further complication. Our age assessment for the Marádah Formation around the Marádah Oasis supports the age valuation of Maštera (1985). The later author assigned a Lower-Middle Miocene age to the deposits of the Marádah Formation. He considered the lithological boundary between the lower Qárat Jahannam Member and the upper Ar Ráhlah Member as diachronous as a reflection of the change of facies due to the deposition in the Sirt Basin.

In the current research, the Marádah Formation at the southwestern outcrops (S1 and S2) is represented by the lower Qárat 
Jahannam Member and the upper Ar Ráhlah Member. Both units, however, are representing the so-called continental and the carbonate phases mentioned in earlier studies. The lower Qárat Jahannam Member is interpreted to deposit in the Lower Miocene (Aquitanian-Burdigalian) based on its stratigraphic position. It rests on an erosional surface of submarine origin in S1 above a $0.5 \mathrm{~m}$. thick of a nummulitic unit of the Oligocene Bu Hashish Formation. The boundary between the lower Qárat Jahannam Member and the upper Ar Ráhlah Member has been set based on a major facies change and supports by the recovery of the first aberrance of the larger benthic foraminifera Borelis melo melo (Fichtel \& Moll). The recovery of this subspecies from the washed residue of SRF1 and in thin-section from SRF3 indicates that the upper Ar Ráhlah Member is Middle Miocene (Langhian and Serravallian) in age.

The Marádah Formation at the northern outcrops (S3 and S4), however, is represented only by the upper Ar Ráhlah Member and the lower and upper contacts with the underlying Qárat Jahannam Member and the overlying Wadi Yunis Member of the Al Khums Formation are not recognized in these localities. Herein, the lower part of Ar Ráhlah Member is denoted by NRF1-NRF3, which primarily resembles the continental-dominated phase mentioned above, and consequentially the sediments have been assigned to the Lower Miocene (Aquitanian-Burdigalian). The overlying facies (NRF4-NRF7), nevertheless, are corresponding to the carbonate-dominated phase in the region, and the deposits have been ascribed to the Middle Miocene (Langhian and Serravallian) based on the total-stratigraphic range of Borelis melo melo (Fichtel \& Moll) which recovered from the washed residues of NRF4 at both sections (S3 and S4) and NRF7 at section three (S3).

\section{Acknowledgment}

The authors would like to thank Mr. Saleh Dawood (Higher Institute of Science and Technology at Marádah) and Mr. Mohamed Lahewale (Faculty of Petroleum Engineering at Zallah) for providing logistics and encouragement for carrying out this research. Thanks are also due to Mr. Ali Almahdi for his support during our stay at Zallah City and to Mr. Abdeljaleal Alnaduwri (GescoLibya at Benghazi) for providing some other logistics assistance and helping during the fieldwork.

\section{References}

Abdulsamad, E. O. (2000). Contribution to the Nummulites Taxonomy from the Palaeogene Sequences of AI Jabal al Akhdar (Cyrenaica, NE Libya). Revue de Paléobiologie, 19(1), 19-45. https://doi.org/10.1144/jm.18.1.45

Abdulsamad, E. O., \& Tmalla, A. F. (2008). A Stratigraphic review of the Al Bayda Formation, NE Libya: Calcareous nannofossils versus foraminifera. Petroleum Research Journal, 21, 57-66.

Abdulsamad, E. O., Bu-Argoub, F. M., \& Tmalla, A. F. (2009). A Stratigraphic review of the Eocene to Miocene rock units in the al Jabal al Akhdar, NE Libya. Journal of Marine and Petroleum Geology, 26, 1228-1239. https://doi.org/10.1016/j.marpetgeo.2008.06.003

Abdulsamad, E. O., \& El Zanati, S. M. (2013). Miocene benthic foraminifera from the Soluq area, NE Libya: biostratigraphy and environmental significance. Journal of Mediterranean Earth Sciences, 5, 245-256. https://doi.org/10.3304/JMES.2013.002

Abdulsamad, E. O., EL-Ekhfifi, S. S., \& Muftah, A. M. (2018). Stratigraphy and larger benthic foraminifera of Middle Eocene to Middle Miocene rocks along the Tobruk-Al Bardia scarps, Northeastern Cyrenaica, Libya. Stratigraphy, 15(3), 123-141. https://doi.org/10.29041/strat.15.3.123-141

Abdulsamad, E. O., Emhanna, S. A., Asmaeil, M. B., Alwddani, A. A., Rasheed, F. M., Alhaddadi, A. M., ... El Hassi, M. F. (2020a). Stratigraphy and sedimentology of Upper Cretaceous to Upper Palaeocene succession in Zimam Formation along Wadi Tar al Kabir, NW Libya. Earth Science Research, 9(2), 1-20. https://doi.org/10.5539/esr.v9n2p1

Abdulsamad, E. O., Emhanna, S. A., Asmaeil, M. B., Alwddani, A. A., Rasheed, F. M., Alhaddadi, A. M., \& Alashhab, E. A. (2020b). Stratigraphic styles of the Upper Paleocene-Lower Eocene rocks along the escarpment of Jabal Waddan, NW Libya. Libyan Journal of Science \& Technology, 11(1), 16-27.

Abdunaser, K. M., \& McCaffrey, K. J. W. (2015). A new structural interpretation relating NW Libya to the Hun Graben, western Sirt Basin based on a new Paleostress inversion. Journal of Earth System Science, 124(8), 1745-1763. https://doi.org/10.1007/s12040-015-0631-4

Adams, C. G. (1984). Neogene larger foraminifera, evolutionary and geological events in the context of datum planes. In Ikebe, N. \& Tsuchi, R. (Eds.), Pacific Neogene Datum Planes: 44-67, University of Tokyo Press, Tokyo.

Ali, M. S. (2014). Miocene Scutellina (Echinoidea), from the northern part of the western desert, Egypt. Cainozoic Research, 14, 119-134. 
Argyriou, T., Cook, T. D., Muftah, A. M., Pavlakis, P., Boaz, N. T., \& Murray, A. M. (2016). A fish assemblage from an Early Miocene horizon from Jabal Zaltan, Libya. Journal of African Earth Sciences, 102, 86-101. https://doi.org/10.1016/j.jafrearsci.2014.11.008

Barr, F. T., \& Weegar, A. A. (1972). Stratigraphic nomenclature of the Sirte Basin, Libya. The Petroleum Exploration Society of Libya, Tripoli, 179p.

Benfield, A. C., \& Wright, E. P. (1980). Post-Eocene sedimentation in the Eastern Sirte Basin, Libya. In Salem, M.J., Hammuda, O.S. \& Eliagoubi, B.A. (Eds.), Second Symposium on the Geology of Libya, pp.463 - 499, London (Academic Press).

Bentham, P. A., Talling, P. J., \& Burbank, D. W. (1993). Braided stream and floodplain deposition in a rapidly aggrading basin: the Escanilla Formation, Spanish Pyrenees. Geological Society of London, Special Publications, 75, 177-194. https://doi.org/10.1144/GSL.SP.1993.075.01.11

Berggren, W. A. (1967). Biostratigraphy and planktonic foraminiferal zonation of the Tertiary System of the Sirte Basin of Libya, North Africa. In Brönnimann, P. \& Renz, H.H. (Eds), Proceedings of the First International Conference on Planktonic Microfossils, Vol. 1, 104-120, E.J. Brill, Leiden.

Betzler, C., \& Schmitz, S. (1997). First record of Borelis melo and Dendritina sp. in the Messinian of SE Spain (Cabo de Gata, Province Almeria). Paläontologische Zeitschrift, 71, 211-216. https://doi.org/10.1007/BF02988489

Buatois, L. A., Mangano, M. G., Alissa, A., \& Carr, T. R. (2002). Sequence stratigraphic and sedimentologic significance of biogenic structures from a Late Paleozoic marginal- to open-marine reservoir, Morrow Sandstone, subsurface of southwest Kansas, USA. Sedimentary Geology, 1, 99-132. https://doi.org/10.1016/S0037-0738(01)00287-1

Buatois, L. A., Mángano, M. G., Maples, C. G., \& Lanier, W. P. (1998). Ichnology of an Upper Carboniferous fluvio-estuarine paleovalley: the Tonganoxie Sandstone, Buildes Quarry, eastern Kansas, USA. Journal of Paleontology, 72, 152-180. https://doi.org/10.1017/S0022336000024094

Desio, A. (1935). Studi geologic! sulla Cirenaica, sul deserto Libico, sulla Tripolitania e sul Fezzan orientate. Missione scientifica della R. Accad. d'ltalie a Cufra, (1931), Roma. Vol. 1: 480p.

Doust, H. (1968). Paleoenvironment studies in the Miocene of Libya. University of London, Imperial College Ph.D. thesis, 1-254p.

El Ebaidi, S. K., \& Muftah, A. M. (2015). Geochemical and petrographical analyses of Miocene Qarat Jahanam clays of Maradah Formation in Jabal Zaltan, North Central Sirt Basin, Libya. Arabian Journal of Geosciences, 8, 50155021. https://doi.org/10.1007/s12517-014-1561-1

El Hawat, A. S. (1975). Sedimentology and petrography of the Marada Formation (M. Miocene), Sirte Basin, Libya. University of London, Ph.D. thesis, 1-304.

EL Hawat, A. S. (1980). Carbonate-terrigenous cyclic sedimentation and palaeo-geography of the Marada Formation, Middle Miocene, Sirt Basin. In Salem, M.J. \& Busrewil, M.T. (Eds.), the Geology of Libya, Vol. II: 427-448. Academic Press, London.

Flügel, E. (2010). Microfacies of carbonate rocks: Analysis, Interpretation and Application. Springer-Verlag Berlin Heidelberg, 984p. https://doi.org/10.1007/978-3-642-03796-2

Frey, R. W., \& Howard, J. D. (1986). Mesotidal estuary sequences, a perspective from the Georgia Bight. Journal of Sedimentary Petrology, 56, 911-924. https://doi.org/10.1306/212F8A85-2B24-11D7-8648000102C1865D

Frey, R.W., Pemberton, S. G., \& Saunder, T. D. A. (1990). Ichnofacies and bathymetry: A passive relationship. Journal of Palaeontology, 64,155-158. https://doi.org/10.1017/S0022336000042372

Gaziry, A. W. (1987). New mammals from the Jabal Zaltan Site, Libya. Senckenbergiana Lethaea, 68(1-4), 69-89.

Goudarzi, G. H. (1970). Geology and mineral resources of Libya and reconnaissance. U.S. Geological Survey Professional Paper, 660, 104p., Washington. https://doi.org/10.3133/pp660

Harzhauzer, M. (2004). Oligocene gastropod faunas of the Eastern Mediterranean (Mesohellenic Trough/Greece and Esfahan-Sirjan Basin, Central Iran). Courier Forschungsinstitut Senckenberg, 248, 93-181.

Harzhauzer, M., Djuricic, A., Mandic, O., Neubauer, Th. B., Zuschin, M., \& Pfeiper, N. (2016). Age structure, carbonate production and shell los rate in an Early Miocene reef of the giant oysters Crassostrea gryphoides. Biogeosciences, 13, 1223-1235. https://doi.org/10.5194/bg-13-1223-2016

Jones, R. W., Simmons, M. D., \& Whittaker, J. E. (2006). On the stratigraphical and palaeobiogeographical significance 
of Borelis melo melo (Fichtel \& Moll, 1798), and Borelis melo curdica (Reichel, 1937) (Foraminifera, Miliolida, Alveolinidae). Journal of Micropalaeontology, 25, 175-185. https://doi.org/10.1144/jm.25.2.175

Magnier, P., \& de Blegiers, A. (1959). Reconnaissance geologique en Cyrenaique. Unpublished report, companie de petrol Total-Libye. Paris.

Mancosu, A., \& Nebelsick, J. (2016). Echinoid assemblages from the Early Miocene of Funtanazza (Sardinia): A tool for reconstructing depositional environments along a shelf gradient. Palaeogeography, Palaeoclimatology, Palaeoecology, 454, 139-160. https://doi.org/10.1016/j.palaeo.2016.03.024

Mandic, O., \& Harzhauser, M. (2003). Molluscs from the Badenian (Middle Miocene) of the Gaindorf Formation (Alpine Molasse Basin, NE Austria) - Taxonomy, paleoecology and biostratigraphy. Annalen Naturhist, Museums Wien, 104(A), 85-127.

Maštera, L. (1985). Geological map of Libya 1:250,000, Marádah sheet NH 34-9 with explanatory booklet. Industrial Research Center, Tripoli, Libya, 121p.

Megerisi, M., \& Mamgain, V. D. (1980). The Upper Cretaceous-Tertiary formations of Northern Libya: A Synthesis. Department of Geological Researches and Mining. Bulletin No. 12. Industrial Research Centre, Tripoli, Libya, $85 \mathrm{p}$.

Melchor, R., Bellosi, E., \& Genise, J. F. (2003). Invertebrate and vertebrate trace fossils from a Triassic lacustrine delta: the Los Rastros Formation, Ischigualasto Provincial Park, San Juan, Argentina. Asociacion Paleontologica Argentina, Publ. Esp., 9, 17-33.

Miall, A. D. (1985). Architectural element analysis: a new method of facies analysis applied to fluvial deposits. Earth Science Reviews, 22, 261-308. https://doi.org/10.1016/0012-8252(85)90001-7

Miall, A. D. (2006). The geology of fluvial deposits, sedimentary facies, basin analysis and petroleum geology. Springer, Berlin, 582p. https://doi.org/10.1007/978-3-662-03237-4

Milisic, N. (1991). Skoljke i puzevi Jadrana. Split (Logos), 302p.

Nagy, J., Rodríguez-Tovar, F., \& Reolid, M. (2016). Environmental significance of Ophiomorpha in a transgressiveregressive sequence of the Spitsbergen Paleocene. Polar Research, 35, 24192. https://doi.org/10.3402/polar.v35.24192

Pashko, P. (2018). Morave Mt. Oligocene-Middle Miocene succession of Albanian-Thessalian Basin. Bulletin of the Geological Society of Greece, 52(1), 1-44. https://doi.org/10.12681/bgsg.15837

Racey, A. (1995). Lithostratigraphy and larger foraminiferal (nummulitid) biostratigraphy of the Tertiary of northern Oman. Micropaleontology, 41, 1-123. https://doi.org/10.2307/1485849

Racey, A. (2001). A Review of Eocene nummulite accumulations: Structure, formation and reservoir potential. Journal of petroleum geology, 24(1), 79-100. https://doi.org/10.1111/j.1747-5457.2001.tb00662.x

Rasser, M. W., \& Nebelsick, J. H. (2007). Dynamics of an Early Miocene Turritelline gastropod mass occurrence (North Alpine Foreland Basin). GeoAlp, Band 4/Vol. 4, 75.

Reiss, Z., \& Hottinger, L. (1984). Shell producers in the water column. In Reiss, Z. \& Hottinger, L. (Eds), the Gulf of Aqaba. Berlin, Springer, pp. 89-138. https://doi.org/10.1007/978-3-642-69787-6_5

Said, R. (1962). The Geology of Egypt. Elsevier, Amsterdam, 377p.

Said, R. (1990).The Geology of Egypt. Balkema Publication, the Netherlands, 734p.

Savage, R. J. G. (1971). Review of the fossil mammals of Libya. In Gray, C. (Ed.), Symposium on the Geology of Libya. University of Libya, Tripoli, pp. 215-226.

Savage, R. J. G., \& White, M. E. (1965). Two mammal faunas from the early Tertiary of Central Libya. Proceedings of the Geological Society of London, 1623, 89-91.

Savage, R. J. G., \& Hamilton, W. R. (1973). Introduction to the Miocene mammal faunas of gebel Zelten, Libya. Bulletin of the British Museum, Natural History, 22(8), 515-527.

Seilacher, A. (1967). Bathymetry of trace fossils. Marine Geology, 5, 413-428. https://doi.org/10.1016/0025-3227(67)90051-5

Seilacher, A. (2007). Trace fossil analysis. Springer, Berlin, 226p.

Selley, R. C. (1966). The Miocene rocks of the Marada and Jebel Zelten area, Central Libya: A study of shoreline sedimentation. Petroleum Exploration Society of Libya, Tripoli, Libya. 30p. 
Selley, R. C. (1968). Facies profiles and other new methods of graphic data presentation: Application in a quantitative study of Libyan Tertiary shoreline deposits. Journal of Sedimentary Petrography, 35, 363-372.

Selley, R. C. (1969). Nearshore marine and continental sediments of Sirt Basin, Libya. Quarterly Journal of the Geological Society of London, 124, 419-460. https://doi.org/10.1144/gsjgs.124.1.0419

Selley, R. C. (1971) Structural control of the Miocene sedimentation in the Sirte Basin. In Gray, C. (Ed.), Symposium of the Geology of Libya. Faculty of Science, University of Libya, pp. 99-106.

Sherif, K. A. T. (1991). Biostratigraphy of the Miocene in Al Khums area, northwestern Libya. In Salem, M. J., Hammuda, O.S. \& Eliagoubi, B.A. (Eds.), the Geology of Libya, Vol. IV: 1421-1455. Elsevier, Amsterdam.

Tawfik, H. A., Salah, M. K., Maejima, W., Armstrong-Altrin, J. S., Abdel-Hameed, A. M. T., \& El Ghandour, M. M., (2018). Petrography and geochemistry of the Lower Miocene Moghra Sandstones, Qattara Depression, north western Desert, Egypt. Geological Journal, 53(5):1938-1953. https://doi.org/10.1002/gj.3025 1938-1953

Tucker, M. E. (2011). Sedimentary rocks in the field: A practical guide (geological field guide). Wiley-Blackwell, Chichester. 275p.

Wessels, W., Fejfar, O., Peláez-Campomanes, P., van der Meulen, A., \& de Bruijn, H. (2003). Miocene small mammals from Jebel Zelten, Libya. Coloquios de Paleontologíal, 699-715.

Wessels, W., Fejfar, O., Peláez-Campomanes, P., Van der Meulen, A., de Bruijn, H., \& El-Arnauti, A. (2008). The age of the small mammal faunas from Jabal Zaltan, Libya. In Neogene Paleontology and Geology of Sahabi. Alan R. Liss, New York, pp 129-138.

Wielandt-Schuster, U., Schuster, F., Harzhauser, M., Mandic, O., Kroh, A., Rögl, F., ... Piller, E. E. (2004). Stratigraphy and palaeoecology of Oligocene and Early Miocene sedimentary sequences of the Mesohellenic Basin (NW Greece). Courier Forschungsinstitut Senckenberg, 248, 1-56.

Wright, E. P., \& Edmunds, W. M. (1971). Hydrogeological studies in the central Cyrenaica. In Gray, C. (Ed.), Symposium of the Geology of Libya. Faculty of Science, University of Libya, Tripoli, pp. 459-481.

\section{Copyrights}

Copyright for this article is retained by the author(s), with first publication rights granted to the journal.

This is an open-access article distributed under the terms and conditions of the Creative Commons Attribution license (http://creativecommons.org/licenses/by/4.0/). 